Illinois State University

ISU ReD: Research and eData

Theses and Dissertations

$3-25-2020$

\title{
No "Me" Before The Nation: Portrayal Of Nationalism And Religious Identities In Bollywood Movies Created During Modi-Era
}

Misha Khan

Illinois State University, mishaaaslamkhan@gmail.com

Follow this and additional works at: https://ir.library.illinoisstate.edu/etd

Part of the Communication Commons

\section{Recommended Citation}

Khan, Misha, "No "Me" Before The Nation: Portrayal Of Nationalism And Religious Identities In Bollywood Movies Created During Modi-Era" (2020). Theses and Dissertations. 1294.

https://ir.library.illinoisstate.edu/etd/1294

This Thesis is brought to you for free and open access by ISU ReD: Research and eData. It has been accepted for inclusion in Theses and Dissertations by an authorized administrator of ISU ReD: Research and eData. For more information, please contact ISUReD@ilstu.edu. 


\section{NO “ME" BEFORE THE NATION: PORTRAYAL OF NATIONALISM AND RELIGIOUS IDENTITIES IN BOLLYWOOD MOVIES CREATED DURING MODI-ERA}

\section{MISHA KHAN}

\section{Pages}

This study analyzed three Bollywood films, Raazi, PM Narendra Modi, and Gully Boy, that were released during the administration of the current Prime Minister of India, PM Narendra Modi. The research questions focused on the portrayal of nationalism and religious identities in the analyzed films. The recurring theme in all three films remained to be nationalism However, drawing on the past research, this study found an existing intertwined relationship between the portrayed nationalism and religious identities. Other central themes in the films included patriarchy, the notion of Othering, and class hegemony. This study draws added implications through its results and past research in the area.

KEYWORDS: Media Representation, Nationalism, Religious Identity, Bollywood 
NO “ME” BEFORE THE NATION: PORTRAYAL OF NATIONALISM AND RELIGIOUS IDENTITIES IN BOLLYWOOD MOVIES CREATED DURING MODI-ERA

MISHA KHAN

\author{
A Thesis Submitted in Partial \\ Fulfillment of the Requirements \\ for the Degree of \\ MASTER OF SCIENCE \\ School of Communication \\ ILLINOIS STATE UNIVERSITY
}


(C) 2020 Misha Khan 
NO “ME” BEFORE THE NATION: PORTRAYAL OF NATIONALISM AND RELIGIOUS IDENTITIES IN BOLLYWOOD MOVIES CREATED DURING MODI-ERA

MISHA KHAN

COMMITTEE MEMBERS:

John R. Baldwin, Chair

Megan Hopper

Philip Chidester 


\section{ACKNOWLEGMENTS}

I would like to thank my advisor Dr. John Baldwin for his kindness, guidance, and support throughout my journey as a graduate student, and specifically in shaping this project and steering me into right direction when I needed. I also owe many thanks to my committee members, Dr. Phil Chidester and Dr. Megan Hopper, for their feedback and guidance. I am deeply grateful to the wonderful people of School of Communication: To Dr. Andrew Ventimiglia, for his guidance and all the resources, Dr. Kevin Meyer, for his support during my admission process and being a wonderful advisor, and Dr. Cheri Simonds, for being a great supervisor and mentor.

I would like to thank the two amazing people I lost this past year, but I know would have been proud of my progress; Nawaz Baloch and Wahid Baksh, thank you for teaching me the value of education, and for many other life lessons. I would like to pay my deepest gratitude to my parents. Aslam and Raheela. Baba, I would not have been where I am without you, thank you for believing in me. Mama, thank you for your unconditional love and support. I would like to thank my siblings, Sara and Taha, for the love and much needed laughs. I would also like to thank Hasnaa Touita, for being a wonderful friend, and Gilbert Kipkoech for being a dear friend and mentor. 


\section{CONTENTS}

Page

ACKNOWLEGMENTS

$\begin{array}{ll}\text { CONTENTS } & \text { ii }\end{array}$

CHAPTER I: INTRODUCTION 1

$\begin{array}{ll}\text { Modi Era } & 3\end{array}$

$\begin{array}{ll}\text { Conclusion } & 6\end{array}$

$\begin{array}{ll}\text { CHAPTER II: LITERATURE REVIEW } & 7\end{array}$

$\begin{array}{ll}\text { Globalization and Bollywood } & 7\end{array}$

$\begin{array}{ll}\text { Nationalism in Bollywood } & 8\end{array}$

$\begin{array}{ll}\text { Post-Colonialism } & 10\end{array}$

Media and National Identity 13

$\begin{array}{ll}\text { Representation of Other } & 14\end{array}$

$\begin{array}{ll}\text { Orientalism } & 18\end{array}$

$\begin{array}{ll}\text { Re-Orientalism } & 20\end{array}$

$\begin{array}{ll}\text { Conclusion } & 23\end{array}$

$\begin{array}{ll}\text { CHAPTER III: METHOD } & 24\end{array}$

$\begin{array}{ll}\text { Text } & 24\end{array}$

$\begin{array}{ll}\text { PM Narendra Modi } & 24\end{array}$

$\begin{array}{ll}\text { Raazi } & 26\end{array}$

$\begin{array}{ll}\text { Gully Boy } & 28\end{array}$

$\begin{array}{ll}\text { Data Analysis } & 29\end{array}$

$\begin{array}{ll}\text { Conclusion } & 30\end{array}$ 
Nationalism

Nationalistic Identity

Sacrifice

Nation Before Everything

Religion

Raazi

PM Narendra Modi

Gully Boy

Othering

Raazi 50

Gully Boy

PM Narendra Modi

Class Hegemony

PM Narendra Modi

Gully Boy

Patriarchy

Raazi

PM Narendra Modi

Gully Boy

Conclusion 
$\begin{array}{ll}\text { Religious Identity } & 65\end{array}$

$\begin{array}{ll}\text { Nationalism } & 65\end{array}$

$\begin{array}{ll}\text { Religious Identity and Nationalism } & 66\end{array}$

$\begin{array}{ll}\text { Other Key Findings } & 67\end{array}$

$\begin{array}{ll}\text { Implications } & 71\end{array}$

$\begin{array}{ll}\text { Conclusion } & 73\end{array}$

$\begin{array}{lc}\text { REFERENCES } & 74\end{array}$ 


\section{CHAPTER I: INTRODUCTION}

Home to some of the world's most ancient surviving civilizations, the Indian subcontinent spreads vast from the mountainous Afghan frontier to the jungles of Burma and the coral ranges of the Indian Ocean. It is varied in terms of people, languages, and religious and cultural traditions. Specifically, India is known to be the land of many religions. It is the birthplace of four major religions: Hinduism, Sikhism, Jainism, and Buddhism (Hansen \& Parpola, 1986). It has the second highest population of Muslims in the world, next only to Indonesia (Masci, 2017).

The rich history and culture of the Indian subcontinent has always captured the attention of the world. The whole world was left intrigued about the future of the Indian subcontinent when the British rulers agreed upon its split. In 1947, India was officially split into two independent nations, Hindu-majority India and Muslim-majority Pakistan. Following the violent partition of the Indian subcontinent, with estimated death toll of one to two million people (Guardian, 2017) began the vastly complex and largely hostile relationship between the two neighbors.

Soon after their independence, India and Pakistan established diplomatic relations. However, the violent partition and numerous territorial claims have always overshadowed their relationship. Since their independence, the two countries have been involved in three major wars, one undeclared war, and numerous armed skirmishes and military standoffs (Ali \& Ripley, 1983). The Kashmir conflict is the center-point of all these conflicts, with the exception of the Indo-Pakistan War of 1971 and Bangladesh Liberation War, which resulted in the secession of East Pakistan (Cavendish, 2007).

Before the British split the Indian subcontinent, there was no Bollywood. There was just Indian cinema, an industry that was liked equally by subjects of the British Raj. Even after the 
Partition in 1947, the cinema industries of India and Pakistan were not entirely split, but set on alternate paths. The reach of Bollywood cinema is not limited to the enormous 1.37 billion Indian population but has left a spell on audiences all over the globe ("How worried should we be?," n.d.). Interestingly, Pakistan is among the biggest consumers of Bollywood films outside of India (Ahmad, 2019).

Several Bollywood films over the last 72 years have attempted to appeal to the people of India's sense of nationalism, patriotism, and self-sacrifice for the nation. The subjects have ranged from freedom struggle and invasions to battles, sports, ancient and medieval history, and insurgency. The common theme running across these films has been pride in being Indian and duty towards the nation. As early as 1876 , the administration of Lord Northbrook had broadcast the Dramatic Performances Act to stamp out treason on stage (Rajadhyaksha, 2003). The British similarly kept a watchful eye on the films, through the Censor office and Police.

With independence declared on August 15, 1947, things started taking a different turn. More films on nationalism started emerging, showcasing the struggle of a country that had emerged independent through a protracted freedom struggle. Films such as Shaheed (Martyr), Samadhi (Brother-in-law), and Pehla Aadmi (First Man), allegedly based on a true incident surrounding with the struggle of independence were the first ones to surface (IMDB, 2017). In 1952, Anand Math was released, based on a famous novel and directed by Hemen Gupta, a former freedom fighter who had spent years in jail and allegedly escaped hanging. He later turned to the making of films ("Top ten patriotic Indian movies," 2012).

Bollywood films acquired a life of their own when freedom came. In the 1960s, it started to become apparent that the challenges India needed to solve were not merely internal; they sometimes needed military response. The Goa Liberation War (1961), Indo-China war (1962), 
and Indo-Pakistan war (1965) were of the 1960s ("India-China war of 1962," 2016). Another Indo-Pakistan War was followed in 1971. A string of military films followed this, including Haqeeqat (1964), Humsaya (1968), Prem Pujari (1970), Lalkar (1972), Hindustan ki Kasam (1973), Vijeta (1982), and Akraman (1975). Late in the $20^{\text {th }}$ century, films such as Prahaar: The Final Attack (1991), Border (1997), LoC Kargil (2003), Tango Charlie (2005), Shaurya (2008), 1971 (2007), and Ghazi Attack (2017) were created. These films were also based on the IndiaPakistan wars. More films, such as Lagaan (2001), Chak De India (2007), Bhag Milkha Bhag (2013), and Dangal (2016), used sports to raise patriotic feelings (“INDIAN WAR AND PATRIOTIC MOVIES," 2017).

Patriotism did not lose its appeal on film makers in the $21^{\text {st }}$ century. This is proven by the fact that, in the year 2002, three Hindi films were produced based on Bhagat Singh, a freedom fighter from the pre-independence era. Later in that decade more than ten films were released on similar topics (“Top ten patriotic Indian movies,” 2012).

\section{Modi-Era}

In May 2014, India’s Bharatiya Janata Party (BJP) won a majority at a general election after 30 years of coalition governments, leading to the appointment of Narendra Modi as the $14^{\text {th }}$ Prime Minister of India (India Times, 2014). Ever since his victory, PM Modi has been accused of using propaganda to win elections by his opponents and various print media publications. An example is the publication of an Indian magazine called Open with the cover story about the victory headlined "Triumph of the Will." This is also the name of a 1935 propaganda film by German auteur Leni Riefenstahl that was commissioned by the leader of the Nazi Party, Adolf Hitler (South China Morning Post, 2019). In January of 2019 alone, three mainstream Hindi films directly channeled Modi’s positions, policies, or rhetoric (Jamkhandikar, 2019). In the film, 
The Accidental Prime Minister, Modi's predecessor Manmohan Singh is portrayed as a puppet of the prominent Nehru-Gandhi family, known to be first family of Indian politics as three of its members have been prime minister (BBC, 2019). The BJP's approval of the film was made quite clear when it shared a link to the trailer on its official Twitter account (BJP, 2018).

The second film, Uri: The Surgical Strike, dramatized a secret operation conducted by the Indian military against Pakistan in 2016 (IMDB). In the film, a prime minister who is unnamed but looks like Modi is shown as a caring man who stays up late to see how the operation ended and congratulates the team. On January 19, 2019, when Modi officially opened the National Museum of Indian Cinema in Mumbai, he greeted the audience with a line from the film: “How's the josh (energy)?” (South China Morning Post, 2019).

The third film is Manikarnika, an epic period drama based on the life of the queen of a 19th-century princely state who battled the British as part of a series of uprisings across colonial India that came to be known as the Revolt of 1857 . "The difference between you and me is that you want to rule, and I want to serve my people," the title character says to a British officer in the film (Chotiner, 2019). This distinction between ruler and public servant is one that Modi likes to make when comparing himself to the Nehru-Gandhis, often referencing his own humble background as a chaiwala (tea seller).

Elsewhere in the movie, Manikarnika saves a calf from "becoming steak" for the British. Modi's tenure as prime minister has been marked by a large number of horrific killings known as cow lynching, in which people are murdered on suspicion of eating beef or taking a cow for slaughter (BBC, 2019). Cows are sacred primarily to upper-caste Hindus, yet beef is a cheap source of protein for many lower-caste communities. India is also home to the world's second 
largest population of Muslims, as well as a small percentage of Christians. Both these communities eat beef (Doniger, 2019).

The Modi references do not end there. A biopic on the prime minister named $P M$ Narendra Modi was also released right before Modi was elected as the Prime Minister for the second time (Thakur, 2019). Another film, Mere Pyare Prime Minister (My Dear Prime Minister), tells the story of a child from a slum who wants to build a toilet for his single mother. Toilets form an integral part of Modi's flagship Swachh Bharat Abhiyan (Clean India Campaign). Other films to broach the subject include 2017's Toilet: A Prem Katha (Toilet: A Love Story) about a young wife who demanded a toilet in her marital home, sparking a sanitation and social revolution. This film directly references Modi's toilet campaign while also expressing admiration for his controversial demonetization of the 500- and 1,000-rupee currency notes (South China Morning Post, 2019).

Last year, Indian cinema giant Yash Raj Films released Sui Dhaaga (Needle and Thread), appreciating Modi’s Make-in-India and Startup India campaigns, with its against-all-odds narrative of a young couple's small entrepreneurial venture. One of the Modi's most resonant election campaign promises was that he would create 10 million jobs per year (IMDB). In 2018, Modi said 7 million jobs had been created in India, arguably the highest in his tenure as prime minister. Modi has indirectly admitted in a television interview that he considered someone selling small street snacks to be gainfully employed. Sui Dhaaga seemed to channel this selfemployment narrative (Jha, 2018).

There has, in general, been a noticeable increase in nationalistic films over the past five or six years. In 2019 alone, more than ten Bollywood films on the topic of patriotism are being released ("Here are 10 Upcoming Patriotic," 2019). Mostly, this takes the form of the sports 
drama, which offers a loving vessel for nationalism and its iconography unfurling the flag, singing the national anthem, and other such displays. Modern action films also often feature plots about threats to national security or the adventures of the country's many fighting forces. Moreover, even social dramas and love stories are seasoned with such themes; romantic heroes in some Hindi films work on projects of national importance, such as education or finding solutions to women's health issues.

Right-wing populism in democracies all over the world including the Philippines, Hungary, Poland, Turkey, United Kingdom, and the United States seems to be on the rise since the beginning of mid-2010's (Merelli, 2019). When Modi's right-wing Hindu nationalist party came into power in India in 2014, the ever-existing portrayal of nationalism in the Bollywood film industry seemingly increased. The cinema industry, which holds a lot of power over its audience, can serve as tool to influence and amend their thoughts and behaviors.

\section{Conclusion}

This chapter has provided an overview of the circumstances leading to the partition of India and Pakistan, summarized Bollywood movies based on nationalism, and described the face of Indian cinema since the inauguration of PM Modi. The next chapter provide a deeper understanding of Bollywood's impact on its audience and the representation of nationalism and religious nationalism in Bollywood. The broader representations of minorities in media described. 


\section{CHAPTER II: LITERATURE REVIEW}

To understand the representation of nationalism and religious nationalism in Bollywood movies, it is important to review the existing literature on the Bollywood industry, the concepts of nationalism and religious nationalism, and the process of Othering through movies. This chapter provide a deeper understanding of the current global standing of Bollywood film industry, the already explored themes of nationalism in Bollywood movies, the existing relationship between media and national identity, and the concept of Orientalism and ReOrientalism.

\section{Globalization and Bollywood}

Bollywood is not limited to India. In the past few decades it has gone global, and with this global presence the influence of Bollywood on its viewers has increased massively. Globalization has brought an increase in transnational commodification of culture and opened new avenues of cultural dissemination. Bollywood has not only turned into a symbol of popular Asian culture, but its enormous amount of production has made it the largest cinema industry in the world. Bollywood produces nearly 1,000 films every year, which is approximately double that of Hollywood productions (Matusitz \& Payano, 2011). Kaur and Sinha (2005) believe that, if Hollywood signifies the standardized effects of American capitalism in global culture, Bollywood maps the contrasting move of globalization in popular culture. Studying Bollywood films within global context enables the understanding of the conceptual frameworks developed

for Hollywood narratives such as audience voyeurism, narrative techniques, and the effect of Hollywood's cultural capitalism on Indian cinema (Kaur \& Sinha).

Appadurai (1996) outlined the "theory of rupture" (p. 3), which explores the processes of globalization and transitional identity production. Appadurai's approach takes media and 
migration as its twin poles of influence on how modern prejudices are created. Appadurai claims that electronic media, such as the cinema, create communities of sentiment, referring to the groups of people that share the same feelings and thoughts, by offering new resources for selfimagining as an everyday project.

Anderson (1991) viewed nations as imagined communities that can be distinguished by the style in which they are imagined. He also addressed the cultural roots of these imaginings. Anderson emphasized the historical role played by the media in enabling communities of readers to spring up and relate themselves to others in profoundly new ways. He noted the important role played by fiction, which " seeps quietly and continuously into reality, creating that remarkable confidence of community in anonymity which is the hallmark of modern nations', (p. 36).

Takhar, Maclaran, and Lorna (2012) explain how the globalization of Bollywood affects the Indian diaspora at a local level. Bollywood provides an important space for negotiating and reconciling various tensions between family-based and more individualistic value systems. Takhar et al. argue that Bollywood speaks to the diaspora by conveying a new sense of "Indianness," one that is less about citizenship and more about imagined identity and community. They investigated what they termed the "Indian imaginary", and how the values embedded within them impacted the lives of young British Sikhs. Takhar et al. found that Bollywood offers young British Sikhs a hybridized representation of courtship and marriage that is both romantic and familial and that serves to reconcile Eastern and Western marital relationship ideals and oppositional cultural discourses.

\section{Nationalism in Bollywood}

Bollywood films are not solely politically motivated, nor are they entirely devoid of nationalist/anti-colonialist content; however, they are ideologically loaded (Tyrrell, 2004). The 
current Bollywood is the face of post-global India. Ganti (2004) suggests that Hindi cinema endorses nationalist projects that centralize the ideal upper middle-class Hindu male and mark the Muslim man as a sexualized, violent other. Kaur (2002) found that the representations of India no longer seem to be limited to folk dancers in exotic costumes or the sophisticated postures of classical danseuse at the "Festivals of India" abroad (Kaur).

Kinnvall (2004) states that nationalism and religion are both "intimately linked to chosen traumas and chosen glories" (p. 757). This link makes them particularly powerful identity signifiers in times of uncertain structural conditions, with the implication that they are likely to become more persuasive rallying points than other identity-signifiers. Kinnvall believes that there were at least two reasons for this. One can be the link between the history of individualism, nationalism, and religion; another can be found in the close relationship between nationalism/religion and hierarchical race/gender structures.

Friedland (2001) views religious nationalism as a discourse and social movement that are often understood as "an instance of culture's autonomy, a source of identity and critique, or an autonomy manifested in the formation of politicized religious groups" (p. 130). According to Friedland, this is the reason that religious nationalism becomes a movement that defends a specific form of group identity and difference based on the characteristics of individuals. These group identities can be racial, sexual or gender, or linguistic based, and they initiate movements to support particularity from the society's dominant group. Friedland states that religious nationalism serves as an instrument by which religious people secure membership in the political community or recognition in the public sphere.

Religious nationalism can be understood as a part of the new social movement that defends national identity, as opposed to pursuing national political or economic interests 
(Bonnell \& Hunt 1999). Moreover, it can also be understood as a "cultural refraction, or mediation, of underlying social grievances" (Friedland, 2001, p. 130). These castings are based on distinguishing the society as a distributional system of things, including culture as an expressive system of signs, and on understanding the economy as an institutional order and the epitome of the society (Bonnell \& Hunt, 1999). As noted by Reicher and Hopkins (2001), "If national mobilization depends upon national identity, then establishing identity depends upon embedding it within an essentializing historical narrative" (p. 51).

\section{Post-Colonialism}

Post-Colonialism refers to the period that follows the end of colonialism (Childs \& Williams, 2014). However, there is more to the theory than simple transition from one period to another. Childs and Williams state that the completion of one historic period and the beginning of another is difficult to uphold in an unproblematic manner. The colonialization of Indiansubcontinent by the British played an integral part in the construction of different identities based on religious beliefs in the region. Chaturvedi (2001) believes that the idea of two self-contained communities of the Hindus and Muslims in India was only developed with the beginning of British rule.

The two religious communities were defined, demarcated and demonised in terms of certain basic differences: Muslims were violent, despotic, and masculine; Hindus were indolent, passive, and effeminate. Religious identification was accordingly taken as more than a matter of belief; it determined membership more generally in a larger community and also offered valid explanations for the way Indians acted. In short, it was the centrality of religious community, along with that of caste, which for the British marked out India's distinctive status as a fundamentally different land and peoples. (p. 150) 
The British initiated the creation of communitarian identity in India. According to Hassan (2000), this was done by asking the people about their religion, past, and tribes. These were new constructs for the Indians. "The idea of being a Muslim, or being a Brahmin, existed in preBritish times ... But the homogenisation of these categories was a British invention” (p. 189).

Van der Veer (2002) agrees to this notion and states that although a sense of belonging to specific communities existed in pre-colonial India, the relative stabilization of Hindu and Muslim shared identities was mostly a consequence of colonial rule. According to Babar (2002), the colonial policy of "divide and rule" did not invent these communal identities from scratch:

Emerging colonial state, confronted with the task of governing a vast population and territory, had to devise mechanisms for the legitimation of its rule as well as to simplify what it claimed to be an indecipherable complexity of castes and communities having specific characteristics and tendencies. Historians have pointed out that the division of the Indian population into discrete religious communities constituted an integral strategy of colonial practice. This is apparent in many aspects of colonial administration, especially in the sphere of legal institutions and practices. (p. 64)

In the attempt to standardize and decode indigenous law of the Indian subcontinent, the British rulers ended up creating a distinction between Hindu and Muslim laws (Babar, 2002). The census held by the British about religious laws further established these distinctions in terms of a Hindus being majority and Muslims as minority, this became the basis of electoral, representative politics in the sub-continent (Babar).

In India, Bollywood acts as a key player in shaping the nation, its meaning, and signifying its internal and external borders. Rajadhyaksha (2003) notes how, after independence, 
Hindi cinema assembled a national market through the construction of unified, national, gendered, racialized, and (hetero)sexed subject. According to Rajadhyaksha, in many parts of India, the cinema hall has been the only space that was not divided along caste lines. Contemporary Hindi films creates a glossy 'homeland' to the Indian residing around the globe and presents diasporic space as the paradise for the consumer to. According to Mohammad (2006), the concerns in India over the relationship of modernity and consumption to Indian (Hindu) values and identity are ones that the entertainment industries in India needed to address and negotiate (Mohammad, 2006).

The history of the relationship between India and Pakistan is not short of wars and conflicts. India and Pakistan had three wars during 1947-48, 1965, and 1971 (Ganguly, 1995). The first two wars between India and Pakistan were a consequence of the Kashmir issue, which is a direct repercussion of partition of the Indian sub-continent at the end of the colonial era. The third war was due to India's intervention in Pakistan's internal crisis which led to the creation of Bangladesh (Ganguly). The division of West and East Pakistan or current Pakistan and Bangladesh is also an extension of issues formed at the end of the British colonial-era.

Despite the ongoing tensions among the two nations, India and Pakistan have not been involved in a war during the past few decades; However, multiple Bollywood films created in recent times contain the reference to the previous wars to incite nationalism among the Indian viewers. Bollywood films with nationalistic themes are not limited to the stories surrounding military achievements and Indo-Pakistan wars; some films focusing on the themes of colonialism have also been created. One of the examples of the portrayal of nationalism in Bollywood is the film Rang De Basanti (2006). The film places anti-colonial nationalism within the justificatory context of political violence. Rang De Basanti presents a historical narrative that recuperates 
political violence as a crucial moment in the Indian nationalist struggle, by focusing on the revolutionaries who were members of the Hindustan Socialist Republican Association (Army) and who are little studied by historians of the nationalist period (Sirivastava, 2009).

\section{Media and National Identity}

National identity explains the demonstration of identifying with nation, which means that it is relevant to draw on theories of cultural in general. According to Triandafyllidou (1998):

The nation remains the most relevant form of collective identity. The basic propositions of the nationalist doctrine, namely that the world is divided into nations and that the nation is the only legitimate source of political power, are accepted as uncontested principles which guide the development of social and political life. Not only the organization of the world in nation-states seem 'natural' but the whole perception by each individual of the surrounding world is based on the distinction between the ingroup, namely the nation, and the foreigners, those belonging to other communities, the “others." (p. 293)

The notion of the Other is essential in the nationalist doctrine. For nationalists, the existence of their own nation presupposes the existence of other nations too. Traditional cultural forms and practices of the nation are complemented, and increasingly replaced in their affective power, by meanings, images and activities drawn from popular culture. However, this does not make the tradition-bound rituals and other cultural elements irrelevant. According to Ednsor (2002), now their power largely depends on their redistribution through popular culture, where these cultural and traditional rituals blend with countless other iconic cultural elements which signify the nation in multiple and contested ways. 
Madison (1999) writes that European American audiences are generally less interested in shows led by African American actors. Moreover, when European Americans watch "multiethnic" shows, they mostly watch shows that feature European Americans as leads. The representation of Others has been tied up in long-established signifying practices that are slow to change because of systemic media constraints (Fursich, 2010). According to Fursich, if culture is seen as a dynamic process, the media should be situated as institutions that allow for cultural development, and as "enablers and not simply as preservers of cultural diversity" (p. 124). Moreover, makers of media policy and regulation aimed at securing cultural diversity need to be aware of the detrimental effect of censorship and restriction on expression of cultural diversity. As Magder (2004) points out, "Cultural diversity is enhanced when individuals can express themselves freely and receive forms of expression from the broadest possible range of sources, within and across frontiers. Public policy - whether domestic or international - should respect this principle, first and foremost" (p.393).

\section{Representation of the Other}

Numerous studies have shown mass media to articulate dominant social values, ideologies, and developments, and that these characteristics often lead to misrepresentation or stereotypical portrayals of minorities in the media. Hartmann and Husband (1974) investigated ethnic news coverage in Britain during the 1960s and found that the emerging news framework encouraged the perspective of "people of color" as problems, aberrations, or just oddities. Hall (1992) found similar results, as Blacks in the UK were symbolized as less civilized and culturally inferior due to differences in their race and color as compared to the majority. Besides the UK, scholars investigating race relations in the USA in the 1980s also found stereotypical representations of Latinos and other minorities in the American press (Totti, 1987). Van Dijk 
(1991) analyzed two decades of data investigating the relations between media and minority groups across North America and Europe and concluded that the media were representative of a White supremacy, which predominantly depicted minorities as "a problem or a threat, and mostly in association with crime, violence, conflict, unacceptable cultural differences, or other forms of deviance" (p. 20).

When it comes to South-Asia, such characterizations can also be seen in Indian media. Hult and King (2011) found that, since the beginning of the $21^{\text {st }}$ century, terrorism has become a major theme in Bollywood. Bollywood has the power to disseminate and reinforce the already existing ideology of mistrust towards Muslims in the region. Bollywood movies have created the stereotypical images of Muslim characters with religious and cultural symbols such as beards, caps, headscarves, and burqa (Hussein \& Hussein, 2015). These stereotypes ignore the social, economic, cultural, and regional differences in the community. However, the overall representation of Muslims in Bollywood has undergone varied shifts due to the sociopolitical situation of the time.

Islam (2007) believes that the characterization and representation of Indian Muslims is primarily related to the Othering agenda of media in mythologizing and stereotyping the Muslim Other. However, from the perspective of the media, the Muslim Other has to be identified with certain cultural symbols. Those cultural symbols do not need to reflect the everyday traits of the Muslim community in India. Rather, the symbols are often imposed to create a stereotypical and mythical image and then sold as an idealized form (Islam).

During and after the 1990s, Bollywood created an imaginary version of Hindu nation by fabricating the Muslim 'Other' as the enemy of the nation (Khatun, 2016). Most films portrayed the ideological conflict between the nationalist victim and the separationist or "terrorist." This 
played an important role in creating an imaginary Muslim identity in the minds of the audience. Kumar (2013) refers to it as the "techno-cultural transmitter," which is the synergy between technology and culture, where technology is used as a pedagogical tool.

The theme of showing Muslims as terrorists in Bollywood movies became popular during the 1990s (Islam, 2007). However, it was elaborated and diversified during the 2000s, with certain references to terror events since 9/11. An example of this is popular Bollywood film Faana (2006). In Faana, one of Bollywood's biggest stars, Amir Khan, plays the role of a Kashmiri separatist named Rehan, who acts violently against the Indian nation. The film mentions the political ideology of India. Fanaa's cinematic narrative presents the Muslim man in ways that reaffirm violence and sexuality as both sides of a representational coin which appears influenced by Orientalism (Khan, 2009).

Bollywood movies usually construct images of their neighbor country, Pakistan, either to cater the demands of cinema viewers or sometimes also to highlight certain policies that government wants to promote (Roy 2012). Rasul (2011) states that, in the past, many films have been produced by Bollywood had anti-Pakistan content. Movies like Border (1997), LOC: Kargil (2003), and Lakshya (2004) reflected Pakistan as India's enemy country (Rasul 2011). The movie LOC: Kargil was so biased that Pakistanis were hardly shown on screen or even named; they were usually mentioned as rats (Sen, 2005). Gadar: Ek Prem Katha was another anti-Pakistani movie that was based on the partition of Indian Sub-continent in 1947. This film broke the box office records at the time of its release in India (Desai, 2005). Another war movie that depicted the anti-Pakistan content was Lakshya (2004). This movie portrayed the events of the Kargil war which was fought between Pakistan and India in 1999 (Dudrah, 2012). 
Gokulsing and Dissanayake (2012) argued that "the discourse of Indian Popular Cinema has been evolving steadily over a century in response to newer social developments and historical conjunctures" (p. 17). For example, cinema in India has repeatedly addressed queer representations through stereotyped depictions and ambiguous gendered side characters in films such as Raja Hindustani (Indian King) and Laawaaris (Orphans), elemental function of which appeared to be limited to the provision of comic relief (Dharmesh \& Darshan, 1996). Alternatively, a modest number of commercial films presenting queer narratives is also in existence, which, in contrast emphasize the disconsolate or the tragic. The films My Brother Nikhil and I Am, which take HIV and gay bashing/blackmailing as their major themes, are perhaps the most well-known examples of this genre. Another film that can be looked at as queer text is Dostana (friendship). However, Dasgupta (2015) stated that, while Dostana represents queer possibilities existing within the Indian culture and society, it also plays with the negative and positive attributes that we might associate with these characters.

Globally, numerous scholars across disciplines have investigated media representation of Muslims and Islam through various lenses of analytical inquiry, and across varying geo-political contexts. Ahmed and Matthes (2016) presented a meta-analysis of 345 academic studies pertaining to media representations of Muslims and Islam from 2000 to 2015. They found that, Post 9/11, international media focused intensively on Muslims and Islam and the Middle East in particular. This thematic pattern linking Muslims and Islam with terrorism, violence, and orthodoxy ideals highlights religion as a threat.

Muslims are often framed as heartless, brutal, uncivilized, religious fanatics; as militants and terrorists; or as societal problems, within well-constructed war and conflict stories (Shaheen, 2009). Islam is presented from the perspective of a "White man's world," and Muslims are 
categorized as "them" and presented as a threat to "us" (Osuri \& Banerjee, 2004, p. 167;

Abrams, 1988). A social group is a set of individuals who hold a common social identification or view themselves as members of the same social category. Through a social comparison process, persons who are similar to the self are categorized with the self and are labeled the in-group; persons who differ from the self are categorized as the out-group (Sets \& Burke, 2000). Despite living together for a long time, Muslims and Hindus of Indian subcontinent have categorized themselves as a part of different groups on the basis of their religious identities. This grouping has led to the formation of the notion of ingroup and outgroup in India. Moreover, this existence of ingroup and outgroup is somewhat evident in Bollywood films, specifically through the portrayal of its neighboring country, Pakistan.

\section{Orientalism}

This depiction of Muslims as “them" or "others" reflects Edward Said's (1978) notion of Orientalism. Said identified the processes of Orientalism and the relationship between power and dominance where the Oriental was "submitted to being-made the Oriental" (p. 14). Said coined the term Orientalism to refer to the hegemonic patterns of representation of "Oriental" cultures and societies as "backward" and "traditional" in order to construct Europe (or the West) as "modern" and "progressive." The Orient was constantly stigmatized as naturally different from the Occident. This process of othering drew a strict boundary between East and West, and it became "the starting point for elaborate theories, epics, novels, social descriptions, and political accounts concerning the Orient, its people, customs, 'mind', destiny, and so on” (pp. 2-3).

The concept of Orientalism often resonates with the ideals of "racism, Islamophobia, selective prejudice, model minoritizing, and other doctrines of civilization differences" (Kumar, 2012, p. 233). Kumar argued that the discourse of terrorism is another form of Orientalism. He 
explained that this is because terror and torture are frequently denoted as the actions of the Other, never of one's own. Nayak (2006) believed that the event of 9/11 exposed the underlying anxiety always present in the US Self, and that 'Arabs' and 'Muslims' are various constructed categories of Others.

The discursive images of American Orientalism have been profoundly shaped by the historical context of race relations in the domestic U.S. homefront, as well as the nation's diplomatic relations with Asian countries abroad (Lee, 1999). Although Said (1978) focuses mainly on Europe's relations with the Middle East and South Asia, Kim and Chung (2005) argue that the political ideologies and cultural imageries implicit in such hegemonic dichotomies help to shed light on the internal dynamics of Orientalism in America. Specifically, American Orientalism has been sustained by this notion of Western/White power as a means to justify and exert its cultural domination over Asia and Asian America.

While European Orientalism was supposed to defend the colonization and domination of the people from the Third World, American Orientalism was initially used to exclude Asian immigrants from entering or settling in the U.S. (Kim \& Chung, 2005). In support of the exclusion of these prospective immigrants, the mass media started cultivating stereotypes regarding Asian/Americans for the consumption of the White American public. "Everything from the aggressive, ominous images of Japanese and Chinese immigrants during the "Yellow Peril" to more modern depictions of Asian/Americans as the passive "model minority" can be included in this" (p. 74).

The Yellow Peril stereotype led to the exclusion of Asian immigrants and to the colonization of Hawaii, Guam, Samoa, and the Philippines by the U.S. (Lee, 1999). The American version of the Yellow Peril offered reason for excluding Asian immigrants, and 
continuing U.S. westward expansion beyond the west coast of the United States to Asia and the Pacific region (Okihiro, 1994). Hoppenstand (1992) states that the most common stereotype of the Yellow Peril in films, comic books, and cartoons is the "Fu Manchu character, who embodies everything that westerners feared: Asian mastery of Western knowledge and technique” (p. 437).

Caucasian actors starring as Asians characters in films was a common phenomenon in the 1950s and 1960s (Hoppenstand, 1992). In one of the popular films of the period, The Quiet American (1958), based on Graham Green's famous book written three years earlier, the Caucasian actress Georgia Moll played the part of Phuong, the Vietnamese girlfriend of the warweary British foreign correspondent (Hoppenstand).

American Orientalism has existed throughout the U.S. history, but to highlight particular examples of how Orientalism has been engaged to negotiate black racialization, Jun (2016) referred to the "contradictory process of negotiation as 'Black Orientalism' in an attempt to name the critical dilemma that the struggle for Black citizenship (or black political modernity) embodies" (p. 1094).

\section{Re-Orientalism}

Orientalism still exists in both popular and institutional construction of culture and identity. However, it has followed a more interesting course over the last few decades (Lau \& Mendes, 2012). Specifically, Said's (1979) influential arguments have drawn sharp criticism and generated a worldwide scholarly debate about the nature of modernity, colonialism, and empire. In particular, some have argued that Said's concept of Orientalism does not account for the potential for Orientals themselves to use Orientalism in their self-definition (Zeydanlıoğlu, 2008). 
Lau (2009) discusses the notion of re-Orientalism, which views the Orientals as the perpetrators of Orientalism no less than the non-Orientals, stating that Orientals themselves perpetrate certain and selective types of Orientalism. Said's (1979) Orientalism studied how West constructs the Orient and Occident; re-Orientalism focuses on "how cultural producers with eastern affiliations come to terms with an Orientalized East" (Lau \& Mendas, 2012, p. 1). This is done by complying with perceived expiations of western readers, by playing along with them or by discarding them altogether.

Zeydanlığlu (2008) states that there is an intimate and complicit relationship between Orientalism and nationalism, Breckenridge and Veer (1993) refer to this relationship as the "the avatar of Orientalism" (p. 12). The combination of Orientalism and nationalism in the hegemonic discourse is not an exception, as it is a manifestation of Orientalist thinking. When nationalist elites project the internalized Orientalism "inwards" as part of the nation building process, the "native" emerges as "Other" that becomes the target of "corrective" and "scientific" projects of modernity and progress. The transformation of the native is undertaken through a return to the "disciplinary narratives of the West" (Soğuk, 1993: 374).

Lau (2009) argued that the representations of South Asia, South Asian culture, and South Asian women by women writers contain the representations which emphasize and explore the sensitivities, mindsets, expectations, and characteristics of South Asian women. These identities are largely created from within South Asia by the diasporic writers and imposed upon South Asians as representative of their identity, or at least, a significant part of their identity construction.

Mudambi (2013) studied the popular Bollywood movie Slumdog Millionaire through the lens of Orientalism and Othering and found that, although the film brings attention to the social 
ills that exists in the Indian society, the process of "(an)Othering," through the construction of global publics, shifts the focus away from the need for real social change that goes beyond the sentimental fantasy.

Schein (1997) explained the term "self-orientalism" as the "adoption of Western orientalist logics and premises for self-representation in the course of Asian processes of identity production processes that are complicit, in their mimetic quality, with universalist modernizing ideologies" (p. 388). Schein found that in the representations of 1980s China, minority women were filled with contradictions. They were both Othered and incorporated, creating contrast as well as identity. In popular consciousness, they were objects of an uncertain desire that was saturated with other meanings, particularly those concerning the tension between tradition and modernity. "Their imaging betrayed the ascendancy of the Party-as-patriarch over more egalitarian, horizontal visions of the Chinese social order. It was within this complex and highly charged ideological context that minority women and men colluded in reproducing their difference" (p. 403).

The process of Othering from within is not a new phenomenon; research has indicated its presence in Indian popular culture in the past. India has the largest Hindu population and second largest Muslim population in the world (Times of India). The segregation in the Indian society based on religious beliefs has served as decisive in some historic moments of the country. An example of this can be victory of Bhartiya Janta Party (BJP), a right-wing Hindu nationalist party, in the past two general elections of India. The impact of the current government administration on Indian cinema is evident if we look at the new releases of Bollywood.

Although existing research indicates that nationalism in Indian media, whether presented in Bollywood or otherwise, has been studied by scholars in the past, the subtle shift in the themes 
of national identity in the new Bollywood movies is yet to be explored. Moreover, the religious aspects of nationalism in Bollywood are also not adequately studied in the past. This paper explores the renewed depiction of nationalism and national identity, specifically when combined with religion, in Bollywood films. The study focuses on the films produced and released during the reign of current Prime Minister of India, Narendra Modi.

Mainly, this study focuses on the representation of nationalism in Bollywood, and the frames that are used to present it, seeking to address the following research question:

RQ1: How nationalism is portrayed in Bollywood movies created during Modi-era?

Religion has been seen as the divisive line among the people of Indian-subcontinent for a long time. With currently a right-wing Hindu nationalist party being in power in India, it is important to understand how recent movies tackle the subject of religious identities in India. This idea leads to the second research question:

RQ2: How are religious identities represented in the Bollywood movies created in Modiera?

\section{Conclusion}

The purpose of this chapter was to summarize existing literature and provide research questions. Scholars have studied the representation of the people of East or Orientals (as coined by Edward Said, 1978) by the West or Occident. However, the focus on the representation of one's own group has been a comparatively new phenomenon. This study explores a version of this concept and attempts to understand how different identities within a region are portrayed in the films. 


\section{CHAPTER III: METHOD}

The previous chapter provided the theoretical basis for the study with a review of current literature on the history of sub-continent, existence of nationalism and religious nationalism in movies, and overall representation of Others in media. Since this study is focused on the representation of nationalism and religious nationalism in the Bollywood movies. This chapter explains the text that was studied and the method that utilized for data analysis.

Text

Three Bollywood movies, one released in 2018 and the other two released in 2019, named Raazi, PM Nareendra Modi, and Gully Boy respectively, were analyzed for the purpose of this study.

\section{PM Narendra Modi}

The film PM Narendera Modi is a biographical drama film based on the life Narender Modi, the $14^{\text {th }}$ Prime Minister of India. Although the film fared well in the box office, it received a lot of criticism due to its topic, release timing, and depiction of the protagonist.

Production company. PM Narendra Modi was produced by an independent production company called "Legend Global Studio." The company has produced two other films. One of these films, which is also the first film produced by the company, is on the topic of war between India and Pakistan (Legend Global Studio, n.d.).

Bio-pic or hagiography. Critics termed the film as a "hagiography" and stated that film had a clear bias towards the protagonist (CNN, 2019; India Today, 2019). The film was originally supposed to be released on April $11^{\text {th }}, 2019$, more than a month prior the general election in India. However, one day before the election, its release was postponed by the Election 
Commission of India, as it was claimed to be violating the model of code of conduct of elections (Election Commission of India, 2019). The Election Commission of India stated that:

Any biopic material in nature of biography sub-serving the purpose of any political entity or any individual entity connected to it, which has potential to disturb level playing field during the election, should not be displayed in electronic media including cinematograph during the operation of MCC. (Business Today, 2019)

The film was finally released worldwide on May $24^{\text {th }}$, five days after the election day (Kumar, 2019). The trailer and posters were being circulated in the country since January of 2019. However, a new poster was released a day before the eventual release of the film with tag line, Aa rahe hain dobaram ab koi nahin rok sakta, translated: "I am coming back again, nobody can stop me now" (Times of India, 2019).

Plot. The film revolves around the life of the current Prime Minister of India, Narendra Modi. Modi starts his career as a chaiwala (tea seller) and later goes on to become a Sanyasi (Hindu religious mendicant) in the Himalayas. He returns to from the Himalayas and becomes the leader of a volunteer right-wing Hindu nationalist parliamentary organization and later joins his current party, the Bhartiya Janata Party (BJP).

Modi is portrayed an extremely driven man who has a humble beginning, but he becomes the Chief Minister of Gujarat (Westernmost state of India), and later the Prime Minister of India, due to his hard work and determination. When he is young, he is shown fighting alongside the Indian Army against the terrorists in Kashmir region. When he takes the role of the Chief Minister of Gujarat, he portrayed as an excellent administer who builds roads, bring employment opportunities and investment from abroad, eliminates corruption, and handled the 2002's Gujarat riots gracefully. 
In reality, many claim that Modi himself was a key player leading to the Gujrat Riots in 2002. Modi promised the construction of Ram Mandir (Hindu temple) at the place of Babari Masjid (Mosque built in 1528 by the Mughal emperors), but the property was controlled by the Supreme Court of India which did not allow the construction (Ghessem-Fachand, 2012). The riots resulted in the death of 1,044 people, with 223 missing, and 2,500 injured. Out of the dead, 790 were Muslims, and 254 were Hindus (South Asia: Gujarat riot death toll revealed, 2005). The events of 2002 are described as a pogrom by many scholars (Ogden, 2012). Despite this, the movie portrays Modi as a savior and refers to him as an "ideology" than a person during the film.

Nationalism and religion are shown to be a huge part of Modi's journey. From his formal education of Hinduism to his association with Hindu Religious groups, and his physically fighting "terrorists" in Kashmir to his role as a "servant for his people and country", there are numerous references to his ideological attitudes. The film also contains multiple songs that reference religion, the nation of India, and the determination of the protagonist. The film ends with Modi taking oath as the $14^{\text {th }}$ Prime Minister of India.

\section{Raazi}

Raazi is one of the highest-grossing Indian films that feature a female protagonist (Box office India, 2018). The film won the best film award during the $20^{\text {th }}$ International Indian Film Academy Awards (The Guardian, 2019). The film is based on a novel called Calling Sehmat.

The film was released on $11^{\text {th }}$ May, 2018. The timing of the release of this film is crucial since it was around the time of India-Pakistan border skirmishes in Kashmir and retaliatory strikes. The film was banned for release in Pakistan by the Censor Board of Pakistan, due to its content and the political situation (Dailytimes, 2018). 
Production Company. Raazi was produced under the banner of "Dharma Production," which is India's top production house. The production company has produced more than 35 films on a wide-range of topics (Dharma Production, n.d.)

Plot. The film revolves around a strong female protagonist, Sehmat, who is the daughter of a Kashmiri Indian freedom fighter. She marries a Pakistani army officer in order to spy on Pakistan during the India-Pakistan war of 1971. During her time in Pakistan, she develops a communication channel in India but starts falling in love with her husband who has no clue of her actual identity. She discovers important information about Pakistan planning an offense against India and kills her servant and her brother in law. Soon, Pakistan's Intelligence Agencies start cracking down on the area, and several accomplices of Sehmat are arrested.

Sehmat is eventually discovered as a spy by her husband, who confronts her with the police. However, Sehmat's team from Indian Army arrives for her recue, and her husband dies from a grenade launched by them. Sehmat finally returns to India and delivers her husband's child. Through information provided by Sehmat, the Indian Army sinks a Pakistani submarine, which starts the India-Pakistan war of 1971, the surrender of Pakistan, and the birth of a new country, Bangladesh. Sehmat's son is later shown as an Indian Army officer.

The film takes the journey of a twenty-year-old girl, who changes the map of South-Asia. Sehmat is shown as a patriotic hero who goes far and beyond to serve her country. The ideology of nationalism runs in her family, from her father to her son. The film also takes an interesting perspective on religion, as the protagonist and her family are originally Kashmiri Muslims. This gives a message that the Kashmiri Muslims also hold patriotism towards the state of India. The portrayal of India-Pakistan relationship and the overall representation of Pakistan are also very interesting, and again, the Indian nationalist ideology seems to play a major role in the movie. 


\section{Gully Boy}

The film Gully Boy is a coming-of-age film about an aspiring rapper. The film can be described as a unique effort towards closing gap between the Indian hip-hop and the mainstream (Balram, 2019). Gully Boy was released on $14^{\text {th }}$ February, 2019, in India, and it is one of the highest-grossing films overseas for the year of 2019 (Barlam). One of the songs of the film, named "Jingoism," has been deemed controversial by a few film critics, and it has been accused of holding anti-nationalistic sentiments (Aithal, 2019).

Production Company. Gully Boy was produced by “Tiger Baby Films," which is owned by Bollywood film directors Zoya Akhtar and Reema Kagti (Zoya Akhtar and Reema Kagti's..., 2019).

Plot. The film follows the journey of Murad, a final-year college student, who lives in the slums of Mumbai, India. Murad is fascinated by rap music. Murad has an abusive father, Aftab, who brings home a much younger second wife. Murad has a longtime girlfriend Safeena, who is a medical student and routinely meets him in secret. Murad starts writing Rap lyrics when he is forced to work part-time as a driver for a rich family after his father is injured. Murad's lyrics are based on the inequalities that he observes while on the job. Murad soon befriends another rapper, Sher, and an evolving musician, Sky, and he collaborates on a song with them.

As Aftab's violence towards his wife escalates, Murad decides to leave home with his mother and work full-time for his uncle. Later, Murad and Sher enter a contest to open for American rapper Nas's Mumbai concert, and Murad qualifies to the finals after a successful rap battle. Murad gains more confidence by interacting with rap fans who appreciate his performances. Murad finally stands up to Aftab and his uncle when they depreciate his passion. He wins the contest. The film ends with his opening performance, as his friends, family, and 
Safeena watch him proudly in the audience. The film goes beyond class hegemony that exists in the Indian society, and it focuses on the passion and aspirations of a young man who belongs from a lower social class.

The three films chosen for the analysis were all released during the reign of the current Prime Minister of India, Narendra Modi. Modi is the leader of the Right-wing Hindu nationalist political party BJP (Bhartiya Janata Party) (“BJP announces new...”, 2019). Many individuals. including Indian journalists and Bollywood directors, have expressed concern over the influence of Modi and right-wing Hindu nationalist agenda on Bollywood films in the recent years (Dhillon, 2019). Studying the films created during the reign of Modi can help in determining the existence of embedded messages and their impact in Bollywood films.

\section{Data Analysis}

Rhetorical analysis was performed for the purpose of the study. Specifically, the framework of Burke's Pentad analysis was used as a guideline for the analysis. Burke's theoretical framework compares the reality of life to a certain performance (Pramucitra, 2018). According to the theory, just like in a play, life requires actors, scenes, and more tools to aid towards the goals. The dramatic assumption helps towards understanding that "humans are animals that use signs, languages and symbols to form a system that is very important to humans because humans are the makers of choice" (p. 36).

The pentad analysis consists of five points that are used to understand the text: The symbol act along with the background or the media to achieve a particular purpose, scene is a term that defines the concept of background or settings that has a purpose to offer the context of the action, scene is the place for actors to portray an action that describes the situations of society, social values, historical causes, or events, and Agent is the actor that performs the action 
(West \& Turner, 2018). Thje agent may insert personal motivational values such as ideas, desires, fears, rage, instincts, imaginations, and other expressions and act is a discourse in an action. The concept of act comes from two things: character and thought. According to West and Turner (2018), Human character disposes themself to act in certain ways that might be a response to environmental change.

After following the guidelines provided by the framework of a pentad analysis, certain themes were extracted for the better understanding of the text. The themes that are used to explain and analyze the data are nationalism, religion, othering, patriarchy, and class hegemony. First this study provides the description of the relevant scenes, and then analyses of the scenes are done through the explication of themes and the discourse of the selected texts.

\section{Conclusion}

This chapter has presented the procedure that will be followed in this study. The rationale for the choice of the selected text followed by the brief summary of the texts are provided. The chapter also described the proposed process of data analysis. 


\section{CHAPTER IV: ANALYSIS AND RESULT}

This section contains the analysis of films Raazi, PM Narendra Modi, and Raazi, and presents the results. For the purpose of the analysis, details of the relevant scenes are provided with the English translation of dialogues that were originally delivered in Hindi language in the film, the rhetorical meanings behind the dialogues and scenes are discusses, and conclusion is drawn from it.

\section{Nationalism}

Nationalism can be defined as the attitude that individuals have towards their national identity, and the actions that they take to achieve political sovereignty (Neilson, 1998). Nationalism is a prevalent theme in all three films; However, all three films use different lenses to present nationalism. Depiction of nationalism in all three films is analyzed below:

\section{Nationalistic identity}

Nationalism is portrayed as an important individual identity in two out of the three analyzed films.

Raazi. In the film Raazi, nationalism is depicted as a glorified part of individual's identiy. The first scene of Raazi is set at the Arabian Sea. An Indian Army officer is giving a speech:

It has been 46 years, since the three defense forces of our country came together and won a war against Pakistan, in 1971, and severed a part of Pakistan away from it. Those senior officers who have witnessed that war can never forget the sacrifices of that time. Not just the ones who fought the war - but even those who were miles away from the front helping our forces. The brave agents of our Intelligence Bureau. Their glorious feats are 
still fresh in my mind. Among them, was a 20 -year-old girl - who crossed all imaginable limits!

The first dialogue of the film discusses the victor of India in Indo-Pakistan war of 1971. The army officer in the film refers to Bangladesh as a "severed part" which was taken away from Pakistan. The people involved in the war are referred as "brave" with "glorious" achievements, who made "sacrifices" and even "crossed all imaginable limits" for their country. The most prominent theme here is the representation of nationalism as a glorified part of identity building. As Triandafyllidou (1998) indicates, nationalism still serves as the most binding force for the formation of collective identity of the society. This identity creates the notion of Other for a society. This scene emphasizes that sacrificing for the nation is glorious. In another scene of the film, the protagonist Sehmat is portrayed to be saying, "I am the nation, I am India" which emphasizes on the national identity being the most important identity of an individual.

In film Raazi, Sehmat is married to a Pakistani Army officer's son in order to spy in Pakistan. While Sehmat is in Pakistan, it is revealed that the relations between India and Pakistan are becoming very hostile. In one of the scenes, Sehmat's father in law starts to discuss politics at the dinner table with his family and Sehmat, and he says, "This time there is no chance of a compromise. They will be scanning the skies, and we will sweep the ground from under their feet." Here, the film Raazi is presenting Pakistanis as people who are obsessed with the idea of hurting India, as the family would not even spare the topic on the dinner table. Listening to this about India makes Sehmat emotional. Later that night, Sehmat's husband says to her, "I know Abba's (Father) words can be painful. Sorry, Sehmat. My family often forgets that India is your motherland," revisiting the notion of one's country remaining an integral part of one's life no matter what the situation is, or where one might be. 
PM Narendra Modi. Modi repeats the phrase "Jai Hind" throughout the film, which means "long live India". This shows that love for India is an essential part of his identity. Modi is portrayed as a character whose priority is always his country, India. Even when he is a mere teaseller as young boy, he salutes every time he sees the Indian flag. When his friend asks him that why he salutes every time he sees the Indian flag, he responds, "Why do you do this when you go to the temple?" as he presses both of his hands together and bows his head slightly. The gesture, pressing both hands against each other and bowing the head, is done by the people following the Hindu religion whenever they go and pray in the Hindu temple. It donates utmost respect to their gods. Through this sentence, the film presents the idea that, being a nationalist is a significant part of Modi's identity, and country is most important, and its love and respect even surpasses that of religion for the character of Modi. The film continues to compare Modi's strong love for country and his strong association with the Hindu religion on various occasions; however, country always takes the lead. Modi's character continues to show respect towards the Indian flag throughout the film. In one of the scenes, he is shown to be standing up with the Indian flag when the Indian troops are under attack in Kashmir. Modi does not let the flag down amidst open fire from the enemies, as he screams, "Bharat matta ki jay" (Hail mother India). Moreover, when the riots break in Gujarat (state in India), Modi says out loud, "This (Indian) flag will wave in every corner of the country. India will not be afraid of terror; terror will be scared of India."

In his earlier years, Modi joins an Indian right-wing Hindu nationalist paramilitary volunteer organization. He goes through vigorous training to learn to fight for India. During his training at the organization, the character of Modi delivers dialogues that expresses his 
dedication to India. At one occasion, he says, "The people who love the country, do not love anything else." Modi also has the following conversation with his mentor at the organization: Modi to his mentor: I have devoted my life to India. Modi's mentor: You will have to lose sleep if you want to train. Modi: I have so many dreams for my country in my eyes that I do not have any space for sleep.

Just like the film Raazi, PM Narendra Modi is also packed with nationalistic songs. One of the songs in the film contains the following phrases:

My country is asking me when I will pay its debt My sky is asking me when I will perform the righteous behaviour

I have promised mother India that I will not let it bow

I swear to this soil that I will not let this country disappear

Not let this country disappear, not let this country bow

In the song, sacrificing oneself for one's country is indicated as the "righteous behaviour". The song reminds that the people of India hold responsibility towards it, and this responsibility includes that they should bring prosperity to the country, not allow it to bow down to anyone, and not let the country disappear from the world. Another song of the film named "Hindustani" continues to set the Indians apart from the rest of the world and give out the message that Indians are the best. The song contains the following lyrics:

Everyone recognizes us from the name of India

We walk with pride on these streets

Someone who will try to break us will bear the consequences

We have dreams in our eyes, and we salute the flag 
This is a new India, but our ideology is the same old

Listen clearly, the people of this world, do not look at us with evil eye

No matter how much you try, Indians are leading everyone, repeat this after us

We are stubborn, we are used to of winning, we carry love

We will win every star of the sky, we will win the whole universe

India is standing with pride, Vande Matarm! (I bow to the mother India)

Through the plot, dialogues, and songs, the film PM Narendra Modi presents overtly pronationalistic themes.

\section{Sacrifice}

Sacrifice for the sake of nation is also a heavily discussed sub-theme in two out of the three analyzed films.

Raazi. In the film Raazi, the character of Hidayat is revealed to be an Indian spy in Pakistan. In one of the scenes, when Hidayat returns to Kashmir after his meeting with the Pakistani army officer, he has the following conversation with an Indian Intelligence Agency officer, Mir:

Mir: I do not know what to say, Hidayat. I cannot fathom what you have just said. Spying for India - and maintaining contacts in Pakistan is one thing. But an innocent girl, who knows nothing about spying - she is your daughter, Hidayat.

Hidayat: She is an Indian first. You do not know how crucial this time is for India. And how dangerous it can get. They have got a whiff of India's involvement in Bengal, and they will not tolerate it. They will never let Pakistan break apart. They are hatching a big scheme against us.

Mir: What kind of scheme? 
Hidayat: Mir Sahab (Sir), if I knew that would I risk my daughter's life? They have a lot of faith in me which they can only have in my daughter after me.

The notion of sacrifice for one's nation is brought up here. The film introduces Hidayat as a patriot who is willing to put his daughter's life in danger for his country, highlighting the notions of sacrifice and nationalism.

PM Narendra Modi. The notion of self-sacrifice is also a major theme in the film $P M$ Narendra Modi. Modi is portrayed as someone who, throughout his life, loves his country the most, and nothing comes before his country. In the film, when Modi is campaigning for his candidacy for the Prime Minister of India, he receives reports that some terrorists have entered the city of his next rally, and they intend to kill him. Modi decides to go on with his rally despite the threats "for the sake of his nation". He has the following conversation with two of his advisors:

Advisor 1: This is not a media's false report or a political tactic, it is confirmed.

Advisor 2: Terrorists have entered Patna to specifically target you.

Advisor 1: You will have to cancel this rally.

Modi: Media will get a breaking news, and my opponents will get a point that Modi ran away. I do not care about them, but every Indian who is looking at me with hope will be disappointed. How can a person who thinks about his safety first can protect the country? The film is portraying nationalism as an honor, and it is showing that a person who cares for the county more than their life is the person who should be in charge. Similarly, just like Hidayat in the film Raazi, Modi's mother is also taking honour in putting her son in a dangerous situation for the good of the country. Modi's advisor calls his mother and asks her to talk Modi 
out of going to the rally and putting himself in danger. When Modi talks to his mother on phone, she tears up:

Modi: Maa (mother), you are crying?

Modi's mother: No, a fighter's mother does not hold tears in her eyes. She holds pride. I am proud of you. Jai hind.

Modi: Jai hind, Maa!

Modi to his advisors: I will be in Patna (city in India) tomorrow evening at 7 p.m., if I want to change the destiny of this country, first I must face my destiny.

This, once again, is a very nationalistic conversation. Modi's mother is proud to send his son into danger for the sake of her country. When Modi goes to address his political rally, he finds that a lot of people are attending his speech. He addresses the rally:

Modi: You all came here despite such a big threat. This is a message for our enemies that India is more important to us than our own lives. For me, India is my only family. If one and a quarter billion Indians take steps together, then India will move forward one and a quarter billion step forward.

When Modi goes to address the people in the rally, he is depicted as a brave man who is deeply in love with India, and who would do anything for his country. The many Indians who show up to listen to his address are also shown as the noble Indians who care about their country more than their lives, since they are attending the rally despite being aware of the threats.

\section{Nation Before Everything}

The first two films, Raazi and PM Narender Modi, bring up the notion of "Nation before everything" multiples times. 
Raazi. In Raazi, Hidayat brings up his daughter's identity as an "Indian" and says that being an Indian comes before everything else.

One of the conversations goes as following:

Mir: And did you ask Sehmat?

Hidayat: Did my father ask me? He simply informed me and taught me.

Mir: Have you told your daughter about the future you are planning for her?

Hidayat: I will - I will tell her, and you will teach her. If you give her a chance, you will see for yourself. What I cannot accomplish, Sehmat will!

The film depicts that for patriots like Hidayat, duties towards one's nation are a priority and come before everything else, even one's family. The notion of "India first" is seeped into generations. Hidayat's father put him on the line of duty for his country without seeking his say, and Hidayat is willing to do the same to his daughter.

When Hidayat's daughter Sehmat arrives in Kashmir, the following conversation occurs at Hidayat's home between him, his wife (Teji), and Sehmat:

Hidayat: During my last trip to the other side, I became aware of a grave threat to India. Sehmat: War? Again?

Hidayat: The winds of war are blowing in Bengal. And in order to prevent India from interfering, Pakistan wants to do something that will cripple India.

Sehmat: What can they do?

Hidayat: I do not know. This entire situation is a matter of a few months, and I do not have a few months left Sehmat: Mother - 
Teji: He told me last night - what he has known for four months. There is a tumor in his lung, and it is growing.

Sehmat: Why did you not tell me, Abbu (father)? I would have come sooner.

Hidayat: That is why I have called you now.

Teji: No - that is not why you have called her.

Hidayat: We need to be prepared for any emergency - I want you to take my place. I want you to be the eyes and ears for India and live in Pakistan.

Sehmat: How?

Teji: Tell her that, too.

Hidayat: I am telling her, Teji. I am telling her everything -

The idea of India-first appears again in this conversation. Sehmat just found out that her father is going to die soon due to cancer; however, the focus of the conversation remains on India and its safety. This repeats the idea that "nation comes first," as seen earlier in the film.

While Hidayat explains his plan to Sehmat, he makes sure that he is stressing the importance of this task to her, using phrases such as that he wants Sehmat to be the "eyes and ears for India." The notions of self-sacrifice and India-first have been established earlier in film through conversations. Now, playing a major role for the country through putting one's life on the line of duty sounds noble and honorable.

Hidayat informs Sehmat about his plan to marry her to Syed's son and to spy on his family. Later that night, he gets cold feet and goes to Sehmat's room:

Hidayat: I want you to go back to college tomorrow, dear. I do not know what I was thinking. How could I even think about putting you in such grave danger?

Sehmat: Why do you risk your own life for the country, Abbu? 
Hidayat: That is my father's legacy. I did - as I was told. But to make you do the same is a mistake.

Sehmat: So - alright, Abbu. I will go back to college, as you say. But my father, too, has raised me with the same belief- that nothing comes before the country, not even yourself. And if that is a mistake then enrolling your sons in the army to protect the nation is also a mistake.

Nationalism is deeply rooted in the family of Hidayat. His father taught him that his country comes first, and he raised his daughter with the same set of belief. Hidayat is a familyoriented man who loves his daughter a lot; however, country still comes first for him, and his daughter has learned to do the same from him. This dialogue, said in a very emotional tone, refers to the idea of India-first again.

It is interesting to note that Hidayat's character is a Kashmiri Muslim, and he lives in Jammu and Kashmir with his family. Jammu and Kashmir is a region that was administered by the Indian government from 1954 to 2019 and was dissolved in 2019 by Indian government into its own union territory (Reagan, 2019). By presenting a Kashmiri family as extremely loyal to India, the film is reinforcing the image of Kashmiris as people who have been Indian from within all along, and that the loyalties of Kashmiri people lies with the Indian government.

The storyline proceeds and Sehmat rigorously trains with Mir and learns the tactics required for spying. Near the end of the training, the following conversation occurs between Sehmat and Mir:

Mir: Can I ask you a question? Why did you agree to do this? You were studying in college. You must have had some plans for your future. Dreams of your own - 
Sehmat: My father and his father fought in our freedom struggle - I asked him once why did you take those beatings? Spent all those months in jail? He replied with a smile there is no 'me' before the nation.

"No 'me' before the notion" is the clear indication of the idea of India-first in the film. The film represents that the dreams and plans for one's future can be set aside for one's nation, since it comes first. A very strong nationalistic theme can be seen later in the film as well. While spying for India, Sehmat starts to teach a singing class in the military school of Pakistan. The song that she teaches continues to play in the background for a major part of the film. The lyrics of the song are:

My country, my motherland, forever may you bloom

Wherever in the world I roam, you will always remain home

You are my purpose, my very being is you

Wherever I may reach, my reason remains you

I will meet each peril before it touches you

My life at stake forever, always to protect you

From the heart to my lips, my wish rises like a prayer

Like your eternal flame, oh Lord! May my life spread light forever

Nationalism is a major theme in this song. One's country is referred as a home that will always remain home regardless where one might be. Moreover, country is referred as a reason for one's being, and the message of sacrifice for one's country or the notion of "India first" is apparent in the song by statements such as, "I will meet each peril before it touches you." The song itself is very emotional and serves as a backdrop during the scenes where Sehmat performs dangerous spy work. The film is narrating the story of a brave Indian here, who is putting her life 
in danger for her country, and she is willing to do it because that is her purpose: to serve her country.

The presentation of the notion of "nation comes first" can be seen again in the film when Sehmat's husband Iqbal discovers that she is a spy and says that he will have to turn her to the security forces of Pakistan:

Iqbal: But the supreme truth here is that nothing is more important to me, than my country. I love you, Sehmat - But love can never come before the country.

The notion that one's country comes before everything else is repeated here. However, this time the dialogue is not being said by an Indian about India, but a Pakistani about his country. This further implies that one's country is a huge part of one's identity, and the decisions that a person makes are based primarily on that identity. This can be again seen in the film when Syed receives news that his daughter-in-law and friend were Indian spies, as he says, "He was my friend. But how could I forget that he was an Indian after all. It is all my fault."

When the Indian forces fail to safely rescue Sehmat from Pakistan, Mir decides to kill her along with her husband. As he orders to bomb her, he says, "Nothing before the Nation." Repeating the India-first theme again. Sehmat escapes the attack and later goes to Mir's hiding place to confront him:

Sehmat: Killing Iqbal was never part of the plan. Why? Why did you kill him? What loyalty do you preach and practice? You even gave orders to kill me! Mir: That decision was yours. Only you will bear the consequences. Sehmat: I sacrificed my conscience - my life, for you! And you did not even hesitate to take my life. 
Mir: That is the nature of war, Sehmat. Innocent lives are lost in collateral damage. But during war, except for the war, nothing else matters. No one matters. Not you. Not me. No one.

Even though, throughout the film, the themes of nationalism, self-sacrifice, and "India first" are apparent, one of the final dialogues says that sacrificing life for the country is an individual's decision, and they shall bear the consequence as well. No matter what drives the war, it is brutal and has cruel aftermath.

The final scene of the movie shows old Sehmat sitting in a small house in the middle of nowhere. As the following song lyrics are played in the background:

I may not remain, not even in memory

But in safe hands, you will always be.

My country, my motherland - !

The notion of self-sacrifice for country is being brought up. The person who sacrifices for the country does not seek validation, appreciation, or anything in return. This brings back the notion of nationalism. The film shows Sehmat ending up alone and not wanting to do anything with the outside world due to the emotional burden of war. However, the final verses of the song that is played in the film attempt to justify the consequences of war, as nothing else matter as long as the country remains protected. Most of the film gives out a nationalistic message that nothing comes before the nation; Nevertheless, the final scene leaves the depiction of nationalism somewhat ambivalent and neither completely pro or anti-nationalistic.

PM Narendra Modi. Many scenes in the film PM Narendra Modi indicate that "nation comes first" for the character of Modi. As mentioned above, Modi continues to hold his address 
to the public despite the threats, giving the message that his own life matters nothing as compared to the nation, hence the idea that for him nation comes first.

Gully Boy. The film Gully Boy takes a different approach towards Nationalism as compared to the rest of the two films. One of the most popular song of the film is called "Jingostaan", which is a combination between the word Jingoism and Hindustan (India). Jingoism refers to extreme form of nationalism, specifically in a form of aggressive foreign policy (Soanes, 2006). The song attempts to mock the aggression that is held in the name of patriotism. The lyrics of the song are:

Grab them, rip them, cut them, flog them

I want to see deep welts on their skin

Slowly they will confess

Sink the ground beneath their feet

It's 2018 , the nation is in danger

Engulfed in flames, shout them down, scare them all

Play your poisonous flute, Enchant them all

Make them surrender or bleed them dry

Long live Jingostaan! Jingostaan! Jingostaan!

Through these lyrics, the film highlights the thinking that can be harvested due to the presence of extreme nationalism. This extreme form of nationalism can lead towards Jingoism, which causes the creation of hostile foreign policy by a nation. The phrases, "Grab them, rip them, cut them, flog them," "I want to see deep welts on their skin," and "Sink the ground beneath their feet" portray how sentiments of protecting the nation can go far and end up turning into violent acts. The phrase "It's 2018, the nation is in danger" refers to the political situation of 
the region in 2018, when a few right-wing Indian journalists and politicians were found to be advocating for the war between India and Pakistan in the name of protecting the nation. The song continues to call India as "Jingostaan"; the word "staan" in Hindi means land. Jingostaan here is referring to the land of "Jingos." Through this song, the film is criticizing war and unnecessary hatred. Through this song, the film is depicting anti-nationalistic and anti-violence/war message.

\section{Religion}

The theme of Religion is also prominent in all three films.

\section{Raazi}

All the main characters in the film Raazi are Muslim, whether Indian, Pakistani, or Kashmiri. The protagonist Sehmat is a Kashmiri Muslim girl who identifies as an Indian. Sehmat uses the word Allah (God) in the conversation many times, signifying that religion and God are a part of her identity. The first dialogue that the character of Sehmat say to her father is: "Thanks to Allah." The main song that is played through a crucial part of the film "My motherland" include the lines that praise God, and prayers to Him are repeated throughout it, forming the connection between love for country and love for God. Through showing a Muslim family who identifies as Indian and is very nationalist, the film is highlighting that the loyalty of Indian Muslims and Kashmiri Muslims lie with India. Religion is important to the family of Sehmat, but nothing can surpass their love for their motherland India.

\section{PM Narendra Modi}

Religion is central to the identity of the character of Modi in the film PM Narendra Modi. Modi is mostly shown with a tilak on his forehead which is a religious mark worn by people who follow Hinduism. In his younger age, he embarks on the journey to the mountain of Himalayas to 
become a Sanyasi (Hindu religious mendicant). During this time, a song with the following lyrics is played in the film:

My mystic mind cannot find rest, it has been wandering for days and nights

These eyes are tired due to looking for their purpose in all directions

Happiness and sadness are now alien, I cannot get sorrowful for anyone now

My mind is in the position, where everything seems like a lie

My mystic mind cannot find rest, my mystic mind cannot find rest

This song is played in the film when Modi is on a journey to find god, and it stresses that finding god is the purpose of humans and that without god, a person's life is purposeless. Religion is such an eminent part of the film that many of the film posters contains images of the lead character Modi bowing in temple and praying to the Murti (sculpture) of Hindu gods. Throughout the film, Modi is shown as a devout follower of Hindu religion, however his followers belong from different religions. On the other hand, liberal media are portrayed as evil and anti-Modi. In one scene, Modi is giving interview to a journalist:

Journalist to Modi: Our India is a secular country, and people are afraid that you will turn our Hindustan (India) to Hindu-das (Hinduism devoted).

Modi: Do you understand the meaning of Hindustan? Because Hinduism is not just a religion, it is an ideology. Hinduism is the only reason that this country is secular. Because a Pandit (Hindu scholar) who prays to a sculpture is a Hindu for us, and someone who does not believe in the worship of a sculpture is also a Hindu for us. Not from religion, from culture. Only India is such a country, where people perform Namaz (Muslim prayer) on roads, and Ganpati's (Hindu god) rally is also found on the road. Big secular countries such as France and Switzerland have banned hijab, but not in India. 
Pakistan's prime minister can only be a Muslim, but in India Abdul Kalam sahib (A Muslim man) remained to be the Prime Minister. This is what Hindustan is. Where there is only one thing that is bigger than religion, and it is country.

In the above dialogue, Modi's character initially praises the Hinduism religion for its inclusivity. He later praises the religious policies of India by comparing them to the policies of other countries, such as France, Switzerland, and Pakistan. Through this dialogue the film promotes the good aspects of Hindu religion, but more importantly it highlights the importance of association with one's country. In the last line, Modi says that country is bigger than religion, and this theme recurs throughout the film. Religion is an important part of Modi's character; however, just as with Sehmat's character in the film Raazi, nothing can surpass the love for his motherland. The theme that religion is important, but not as important as the country, reappears through more songs in the film. One of the songs contain the following lyrics:

Indian comes before Hindus and Muslims

We will put on the lamps for Diwali (Hindu festival)

And eat Sawanyan (dessert) on Eid (Muslim fetstival)

Santa also comes here to grants gifts

This soil is my life, this soil is my Geeta (reference to Bhagavad Gita, a holy book in Hinduism)

This soil is my Ramadan (holy month for Muslims), I will not allow it to be erased This is my Khuda (Muslim god), this is my Ram (Hindu god), this is my India.

Another song of the film called Junoon contains similar message that the religious differences are small compared to the affiliation with one's country. The song states that love for the country should be one's religion: 
He is god, He is prophet, He is Ram

What kind of war is on his name?

All the colours for all religions are together on my (Indian) flag

How are the colours for two nations (Hindu and Muslims) different?

What has passed is in the past, there should not be a wall of religion anymore

We should not let any symbol of hatred to survive

We make the country, we are the country

\section{Gully Boy}

Religious beliefs also play an important role in the film Gully Boy. The protagonist Murad is a Muslim character who comes from an Islam practicing family. His girlfriend and her family are also Muslims. The character of Murad wears a Taweez (amulet worn by some Muslims) throughout the film. He goes to the mosque and prays with his father. During two occasions in the film, Murad is offered alcohol to drink:

Murad: No, thanks.

Person: You do not drink? Want something else?

Murad: No

In another scene, Murad sits in a bar with his friend. His friend orders alcohol but when the server asks Murad his order, his friend says no for him:

Murad's friend: One beer.

Server to Murad: And you?

Murad's friend: He doesn't drink. 
Alcohol is prohibited in Islam. By portraying Murad as someone who does not engage in drinking alcohol, the film presents the message that religion is important to Murad. Even in the rap songs that Murad writes and sings, reference to his association to god are evident:

I ask no one for help, I only bow my head before god

I plead to be forgiven, just let it flow, let your truth show

Murad's parents also engage in religious practices. Both his parents wear taweez, and his grandmother covers her head. Murad's father is a part of a polygamous marriage. Polygamous marriages are only performed by Muslim population of India, since it is forbidden in Hinduism. Murad's family also believes in superstitions and believes that things happen due to supernatural forces. When Murad's father starts following his new wife's orders, his grandmother says: "He's taking the TV inside, too. She has put a black magic spell on him." Similarly, when Murad's girlfriend gets into a fight with another girl, he jokingly says to her, "You are possessed with a spirit. I will have to get you exorcised." In one scene, when Murad is recording his rap song on an I-Pad, his mother assumes that he is talking to himself and says, "Hey Murad, you should not talk to yourself, it is bad luck." Murad's father also says phrases such as, "The rest is up to God."

Even though Murad is portrayed as a character who follows religion, the film also discusses the misuse of religion. The film gives the message throughout that, even though he practices religion, Murad still has the ability to question its integrity when necessary. In one of his rap songs, Murad says:

Religion is used for money; so, think, listen, speak up

Stop turning a blind eye, try some virtue

Honesty will not hurt you, clean this dirt! 
In another rap song Murad says, "Art is my religion, and I have no other prayer to fake." The film is portraying Murad as a young progressive Muslim who pursues a career in hip-hop music, which is refreshing. However, the film seems to be repeating many of the existing stereotypes about the Muslims in India, such as that they engage in polygamous marriages, they believe in black magic, or the women are extremely oppressed. Murad is a good student, and he has good morals. Once, he calls out his friend who is using young children to sell drugs, "Moeen, you are using those kids to deal drugs? Shame on you, Moeen." Despite this, he himself commits crime and steals cars when he needs money. The film Gully Boy sustains an overall antinationalistic theme; Nevertheless, unlike the rest of the films, religion is not distinctly linked to nationalism in the film.

\section{Othering}

The notion of Other is depicted in all three films.

\section{Raazi}

The film Raazi presents Bangladeshis as others. In the film, a Pakistani army officer refers to the freedom movement of East Pakistan as solely Mujib-ur-Rahman's "dreams of liberation." The notion of Other is apparent here. Despite the fact that at this time East Pakistan is the part of the country, the people belonging to the region are being seen as Others. Through this scene, the film is justifying the East and West Pakistan partition, since the people of East Pakistan were seen as Other by the people of West Pakistan, and they were not meant to exist together anyway.

The notion of Othering can be seen again in the film when Sehmat gets married and moves to Pakistan. She is warmly welcomed by everyone except the oldest servant of the family, who is cold towards her. Sehmat attempts to help the servant in the kitchen with breakfast. The 
servant refuses her help and asks her not to interfere with the household routine. Sehmat discusses the servant's hostile behavior with her sister-in-law Munira:

Sehmat: When you first came, was he like this with you too?

Munira: Somewhat.

Sehmat: But maybe because I am Indian? Is that why?

Munira: Could be

The notion of Other can be found in this scene as well. When in Pakistan, Sehmat is being viewed as an outsider despite moving to Pakistan for the rest of her life by the servant. The film portrays the message that one's national identity is the most integral part of their identity and it separates them from others.

\section{Gully Boy}

The film focuses on people's identity on the basis of their religion. Murad, the protagonist, belongs from a Muslim family and is seen as Other by some Hindu. An example of this is when Murad visits his Hindu friend, and his friend's father asks him, "Murad, where are you from? Some Muslim ghetto?" Through such incidents the film highlights the discrimination that religious minorities can face in their own country. Another example is when Murad's father finds him a job and asks him to take the job, as "they (employers) are good people, It's tough time for Muslims anyway."

\section{PM Narendra Modi}

The film PM Narendra Modi contains a lot conflict between the Hindu and Muslim community of India. Moreover, Pakistan and its people are portrayed frequently as Others. Pakistan is portrayed as a country that is planting terrorists in India as a result of the political and 
social differences between the two countries. At various occasions the character of Modi calls out Pakistan and tells Pakistan that India is better than Pakistan:

Modi: Today, we are not worried, but those should be worried who could not win from us in the battle zone or cricket ground. That is why they came to fix the match of this election. But, all of you defeated them by coming here.

\section{Class Hegemony}

Class hegemony is the grouping based on power, wealth, and the privilege of social classes in a manner that the elite social class holds the power to exploit the individuals belonging from socially-ranked lower class (Russo \& Bryan, 2013).

\section{PM Narendra Modi}

When it comes to social class hegemony, the film PM Narendra Modi points to its existence in the roots of India and challenges it. The main character Modi is basically a tea-seller who ends up taking oath as the $14^{\text {th }}$ Prime Minister of India. By doing so, he is challenging the existing class hegemony that exists in India. When Modi decides to run for the position of the Prime Minister of India, his opponents mock him for his poor background as his credentials as a former chaiwala (tea-seller). To this, Modi responds:

Modi: They say that a chaiwala cannot become a Prime Minister of a country. Yes, I am a chaiwala. I sold tea; I did not sell the country like them. Every youngster can become the Prime Minister of this country. Every person who sweeps can become the Prime Minister of this country. Every farmer can become the PM of this country. India has changed, Sir. Now the credentials of your father would not do you any good, only your work would. 
The film portrays the existing the class hegemony in India in a negative light. The portrayal suggests that it is possible to break the hegemony that exists in India, and anyone who breaks this hegemony is a brave and noble person. India is turning into a country that provides everyone a chance on the basis of their talent despite their family background, social standing, and financial standing. When Modi finally gets into power, he makes the ministers of his cabinets serve tea to the servants of their office, further smashing the hegemonic system of the country.

Modi: I am asking you to serve, not get served.

\section{Gully Boy}

Many references to the presence of class hegemony in the Indian society are made in the film Gully Boy; however, almost all of them are a criticism towards those who hold power. Murad, the protagonist of the film belongs to a very poor family and lives in a very poor neighborhood. His neighborhood is so poor that tour guides take tourists through their paces to show how poor people in India live:

Tour guide: You can take pictures. And this is the toilet. This is for the whole community.

Tourist: How many people are in the community?

Tour guide: Lots! The other one is being built over there. Come, I'll show you.

The Tourist, while visiting Murad's house:

Tourist: Crazy, isn't it? Every inch is being used. It's incredible. How many people live here?

Tour guide: I have no idea.

Tourist: So small! 
Class hegemony is apparent in the scenes, some people are so poor that they have become the reason for the amusement for another social group. The film highlights the social divide between higher and lower income groups. Murad, who aspires to become a famous rapper, writes about the sad reality of his life:

Why is every eye moist in this shantytown?

Days turn to poison once the sun goes down

Restless and troubled are those who live here

In this bottomless well where they'll drown

Here, the film provides a channel of expression to the people whose voices are not heard by the people in power. The people who spend their life in extreme poverty often end up dying in these circumstances. The film is shedding light on the less privileged people and their struggles. In one scene, Murad's mother says to his father, "I have big dreams for him (Murad)," and his father responds, "Dreams? Who do you think you are? Look around. Make sure your big dreams match your reality."

The film further deals with class hegemony, through discussing how deep roots of class hegemony in the society prevent people from growing out of their social class system despite having the skill and talent. Murad works as a driver for a rich woman. As Murad drives the woman, her husband, and her daughter around town, the husband has the following conversation with his daughter who does not want to go to graduate school, and Murad:

Husband: How educated are you?

Murad: I am in my final year of graduation, sir.

Husband to his daughter: Did you hear that? Everyone's a graduate today. And you want to be on the same level as he is? 
Murad is remined of his social class and his destiny being tied to it in another scene where he has a conversation with his uncle. When Murad starts working for his uncle to support his mother and little brother, he decides to also audition for a rapping contest. He approaches his uncle to ask for a day off to participate in the initial audition:

Murad: I have some work tomorrow. I need to go somewhere. Can I have the day off? Uncle: Where are you going on a picnic? Murad: There's a contest I'm taking part in. It's the first audition. Uncle: Where did you learn such fancy words? Your father is a driver, remember? A servant's son is a servant. It's the law of nature.

However, through the complete storyline, the film criticizes the class hegemony in the country and gives a message that it is possible to break this divide between rich and poor. The final conversation between Murad and his father goes as following:

Aftab: Call Ateeq and apologize (for leaving work)

Murad: I will not call him. He called us servants.

Aftab: But we are servants.

Murad: That means we serve and work hard. We aren't slaves. Whatever we are, we deserve respect.

The Social class difference is also pointed out through the lyrics of the rap songs in the film:

I cannot reach out to you, I cannot wipe your tears

My standing won't let me,

You are near, Yet we're a world apart

Why are my hands tied? Can anyone tell me 
Why this divide, this disparity?

Who pulls the strings? Who writes the story?

Who writes the story?

The film also focuses on the power of expression to break the class hegemony in India. References to the power of expression are made in various scenes of the film. The lyrics of the song that are played multiple times during the film are:

The lava of my words will melt my shackles

You will reap as you shall sow

My dreams will make fear tremble

You can't bury dreams six-feet-under

No fear, only guts!

We will storm ahead, we will seize the day

Blood and sweat gave our life meaning

Why? because our time will come!

You were born naked; you will take nothing with you

\section{Patriarchy}

Patriarchy and its impact is present in all three films.

\section{Raazi}

When Hidayat first asks his daughter to spy in Pakistan, Sehmat's mother Teji hints her distress towards sending her daughter away by asking her husband to come clear about his motives. However, this does not seem to bother either Hidayat or Sehmat. This reflects on the hegemony rooted in the family system in the subcontinent. Mothers, despite playing a major role 
in raising children, are often left out of making important life decisions for children by the head of the families.

The film presents Hidayat's household as a very typical sub-continental household where a man is the head of the family and has the ability to make decisions for the women. He is not worried about the consequences of making a major decision on the behalf of his daughter because his country is in a crucial situation and needs her. However, the film seems to go beyond the gender roles in the society of sub-continent, as Sehmat, who is a girl, is being sent to spy and train with male colleagues.

\section{PM Narendra Modi}

The film PM Narendra Modi presents the character of Indira Gandhi (the only female Prime Minister of India) as determined political leader. However, almost every other female character in the film is portrayed as helpless. Modi's mother plays a huge role in his personality building. Modi highly respects his mother, deeply cares about her, and does not take any step without her approval. This portrays the role of Indian women in the Indian society and towards raising their children. As an adult Modi builds a well for the women of a village who do not have access to water. While building a well, Modi says, "Until the women of India are helpless, this country can never become strong."

This is shown as an act of empowering women. However, in a broader sense, this just reinforces the existing ideology of Bollywood that women require strong men to rescue them and empower them.

\section{Gully Boy}

The theme of patriarchy appears throughout the Gully Boy. In the beginning of film, the protagonist Murad's father Aftab remarries and brings his second, much-younger wife home. His 
first wife, Murad's mother Razia, performs all the chores for her husband's second wife as her husband asks her. Murad shows distress about the situation to his uncle, Razia's brother Ateeq: Murad: Maa is very unhappy, uncle.

Uncle: There is nothing I can do.

Murad: She is your sister...

Uncle: And he is her husband.

Through this scene, the film provides a glimpse of the patriarchy that exists in the Indian society in a negative light, where a woman's destiny is held in the hand of the men in her life. Razia silently suffers as her husband lives a happy life with his new wife. One day Razia and Aftab gets into an argument over Murad's singing and it gets directed toward Aftab's second marriage:

Razia: Did you ask me before remarrying? Now fix it.

Aftab: Tell Murad not to strut about.

Razia: Brilliant solution!

Aftab: If you're leaving it up to me, pack your bags and get out!

Razia: You want me to leave? I should go?

Aftab: Stop! I am being polite.

Razia: Polite? You brought another woman to my bed.

Aftab: Yes, I did! You weren't of much use on that bed anyway!

The film is depicting patriarchy in a negative light by showcasing the entitled thinking of a man in the Indian society, specifically in a Muslim household. Being the head of the family, the man has the power to force the women out of the house. Moreover, the primary purpose of a 
woman is to please a man, and, if she fails to do it, she is useless. The film showcases the injustices in the Indian society on the basis of gender.

Aftab has an abusive relationship with Razia. It becomes very prominent when he starts to beat her whenever she becomes vocal:

Aftab: Ungrateful wretch!

Razia: Beat me! I won't keep quiet now! Go ahead, slap me!

Although Murad is always very respectful to his father. He physically jumps in once his father beats his mother in front of him

Murad: Abu! Don't you dare hit her! I'll call the police--don't hit her! The police will straighten you out. Don't touch her.

This is a classic example of good versus bad man. A bad man hits woman, and a good man protects her. As refreshing as it sounds during the grim scene of injustice, this scene still gives the message that an Indian woman needs a male to save her. Razia could have threatened to call the police herself, but her son had to jump in and save her. Despite being a woman herself, Murad's grandmother finds Murad's behavior toward his father to be rude and blames Razia for it:

Murad's grandmother: Is this how you've raised him? No wonder your husband brought home a new wife. Is this what you've taught him?

This is the presentation of the pressure on women to be a good mother and to raise obedient children. And any woman who fails to do her job deserves to be replaced. This harsh face of society again becomes apparent in the film when Razia leaves her husband and asks her brother for help:

Razia's brother: You want to leave your husband and want me to help you? 
Patriarchy is also portrayed in the film Gully Boy through the storyline of Murad's girlfriend Safeena. Safeena gets into a fight with another girl, Albina. As a result, the parents of both girls are called by their teachers. The following conversion occurs:

Safeena: You can check her phone, Uncle.

Albina: How can you check-

Albina's father: Shut up!

Albina's father forcefully grabs her phone from her hand and checks it and slaps her. This shows how keeping an eye on the doings of one's daughter is normal. In fact, parents take pride in keeping a close eye on their daughter, as later in the scene, when Albina tells Safeena's parents that Safeena is having an "affair" (relationship with Murad), Safeena gets away by saying:

Safeena: Wouldn't you know if I was having an affair right under your nose?

In another scene, a female singer is shown to be performing in at a college campus. Despite being a good singer, she is booed by some boys in the front of the crowd and she leaves the stage. A male singer walks up to the stage and has the following conversation with the boys: Boys: Get this girl out of here! Male singer: What happened? Those guys were saying something over there. What's going on, guys? Couldn't handle Juhi's talent? Who found the song boring? Boys: The girl was boring!

Male singer: There you are. And if you don't like her, she should shut up, right? Boys: Well said!

Male singer: Come, I'll perform for you. 
The male singer continues to perform a rap song for the audience, mainly gesturing towards the boys as he recites the following lines:

A snake for women, a blemish on mankind

My words have more heat than you

Shame on you! you have no future

You have no strength, Use your head

The wave of truth has flooded the town

Stop throwing your weight around

Watch your step, be true to yourself

Kill your arrogance, end this empty existence

End this hustling, and random muscling

Cool that fever, end this bragging, End this hustling

The male singer calls out the boys on their harmful masculinity and the film puts forward a good message towards women's empowerment. However, the issue remains the same in this scene as well: A woman needs a man to speak for herself.

Safeena studies in the medical college and aspires to be a surgeon; however, her mother repeatedly tries to find her a groom and marry her. Safeena's mother shows her photos of potential matches for marriages:

Safeena: I'm studying.

Mother: You're lucky you get to choose. Nobody even asked us. I was told who to marry and that was that.

This demonstrates how little say young women have even regarding their personal matters. Moreover, the film is highlighting that until this day, for most Indians, education is not 
the most achievement for women, marriage is. Despite this, Safeena is shown as a strong character who is deeply in love with Murad but dreams about building a good future for herself. This can be seen when Murad asks her what she wants to achieve in life:

Safeena: My own medical practice and marriage with you.

Murad: Oh, so I come second?

Safeena: When life gives you something good, shut up and take it.

Safeena's parents are conservative Muslims, who do not allow her to go outside other than for work and study. Safeena often sneaks out to meet her boyfriend, Murad, and male friends. Once, Safeena gets into a fight and her parents find out that she has been sneaking out behind their back:

Safeena's mother: Is this what we've taught you? Then why did you do this?

Safeena: If I tell you the truth, you will never let me leave the house.

Safeena's mother: So, is this our fault, too?

Safeena: I didn't say that. But, did I have a choice?

Safeena's mother: If you don't lie and fight, would your life be ruined?

Safeena: It's already ruined, Ma. My life is confined to college, the clinic, and home. What else do I do? So, what more do you want to do? I want to go out. Party with my friends, watch movies, go to concerts, wear lipstick. Talk to boys. Not secretly but in your presence. I want to invite them home like people do normally.

Safeena's heartfelt dialogues seemed to have no effect on her mother, who starts to beat her and grounds her.

Despite Safeena's request, her parents continue to look for a groom for her. They also refuse to let her go back to college. She asks her parents when she can go back to college: 
Safeena's mother: Get married first.

Safeena: Dad? Dad. It's just 18 months to go. This is a crucial year. I can't miss a single lecture.

Safeena's mother: There's no need for that, Safeena.

Safeena: Dad? Say something. You know I'm a brilliant student. You can't pull me out of college. I've apologized. Everyone is talking. Dad, please! Please! Dad, please. Let me study. Please, Dad. I want to study, Dad. I'll marry anyone you want. Please. Please. Safeena's dad: I'll drop you at college myself and pick you up every day. But you'll have to meet suitors.

Safeena: Yes

Safeena also supports the idea of Murad becoming rapper and expresses that she will look after both of them financially, when she says, "You do whatever you like. I am going to be a surgeon; we will have a good life." This is an example where the film portrays a strong headed, independent female character who is achieving of things on her own. The film also contains another strong female character, Sky. Sky is a music student who is interested in working with hip-hop music. Murad agrees to work with Sky thinking that it is a man, but is shocked to find that she is a girl when they first meet:

Sky: Sorry, I am a girl.

Murad: Makes no difference to us, girl or boy.

\section{Conclusion}

The analyzed data were categorized into themes: Nationalism, religion, othering, patriarchy, and class hegemony. First, the description and of relevant scenes was provided, and then the scenes were analyzed through the lens of the themes. Nationalism appeared as the most 
recurring theme. Religion and patriarchy were also common themes among the three analyzed films; however, religion and patriarchy kept rotating back to nationalism in the film. 


\section{CHAPTER V: DISCUSSION}

This study analyses the portrayal of nationalism and religious identity in Bollywood films. Three Bollywood films named Raazi, PM Narendra Modi, and Gully Boy are analyzed for the purpose of this study. The previous chapter provided the description of the relevant scenes along with the analysis. As a result, nationalism, religious identity, and patriarchy appeared as the most prevalent themes in all three films. This chapter further compares these themes with the existing literature, draw implications based on the findings, and discusses limitations of this study.

\section{Research Questions}

The two research questions of this study explored the representation of nationalism and religious identity in Bollywood films during the reign of PM Modi.

\section{Religious Identity}

The most common aspect between the main characters of the films is their association with their religions. Religion plays a major role in the identity building of Sehmat, Modi, and Murad. The characters of Sehmat and Murad practice Islam, they use the word "Allah" in many of their everyday conversations. Both, the families of Sehmat and Murad follows Islam that is presented in a manner that complies with the already existing stereotypes in the Indian media (Ganti, 2004). The character of Modi practices Hinduism and prays to Bhagwan (a Hindu god), and he believes that his religion, Hinduism, is an ideology and a way of life.

\section{Nationalism}

Another common characteristic between the characters of Sehmat and Modi is their love for the nation. Despite religion being extremely important to them, their priority is always their 
country. Through presenting this idea, the two films, PM Narenda Modi and Raazi, are depicting the importance of national identity.

\section{Religious Identity and Nationalism}

The films mainly present intertwined relationship between nationalism and religion. The notion of intertwined relationship between nationalism and religion resonates with the idea of Kinnvall (2004), who states that this link between nationalism and religion makes them, combined, the most powerful identity signifier. Religious association and nationalism interlink for the character of Modi in the film PM Narendra Modi to an extent that he attempts to present Hinduism as an ideology that should be held by every Indian. This corresponds with the belief that religious nationalism can be understood as an instance of the autonomy of culture, source of identity, epitome of society, and a way to defend national identity (Bonnell \& Hunt, 1999; Friedland, 2001).

On the other hand, Gully Boy portrays nationalism through a different lens. Gully Boy takes a seemingly anti-nationalistic approach, as it condemns extremism and violence in the name of love for the country. Extreme nationalism is articulated as a toxic trait in the film, and the people who advocate for war are derided. This is a rather uncommon and unusual take by a Bollywood film, especially when compared to other films that are analyzed in this study, for example Raazi's depiction of nationalism in a positive light, and the overtly pro-nationalistic take by PM Narendra Modi.

Despite separately analyzing the themes of nationalism and religious identities in the films, I have come to the conclusion that these identities are articulated in a highly intertwined manner. National identity is depicted as the most significant identity by the films Raazi and PM Narendra Modi. The characters turn to God to pray for the nation, and they set aside their 
religious differences when the motherland needs them. Religion is an integral part of the lives of these characters; however, it is not as important as their country. When it comes solely to nationalism, two out of the three films look at it through a positive lens and go as far as justifying war and hostile foreign policy of a country through it. However, the third film, which mainly focuses on the youth of India, criticizes spending resources on war. When it comes to religious identity specifically, all three films present it as an important aspect of an individual's life. Religious association is depicted as an empowering identity that every individual must seek.

\section{Other Key Findings}

Nationalism not only surpasses religion, but for the family of Sehmat, in Raazi, it also becomes more important than the gender roles set in the South-Asian society. Patriarchy is a reoccurring theme in all three films. In film Raazi, the opinion of Sehmat's mother is ignored by her father, the head of the family, reinforcing the gender roles in the society. However, gender

roles are set aside for the safety of the nation. Sehmat's father asks her to become a spy and leave her education, and she abides by her father's request due to the obligation towards her country. From this point onwards, the film focuses on the bravery of Sehmat, which supersedes the gender roles that exists in the Indian society. Hence, religion and patriarchy are important for the characters of these films, but nothing is as important as their nation.

PM Narendra Modi and Gully Boy attempt to challenge the existing patriarchy through their storylines. However, in doing so, they also depict the notion of male savior. Women, despite being strong and capable, need men to fight for them, empower them, and provide them with a voice. The characters of Modi and Murad are depicted as the "good" men who want to empower women, and who fight for their rights. However, at various instances during the film, these characters are portrayed to be speaking for women when the women could have been 
speaking for themselves. This also links to the notion of hegemonic masculinity, which is the representation of society's ideal regarding the way men should behave (Kareithi, 2014). Kareithi (2014) believes that the function of hegemonic masculinity is to legitimate the social dominance of men over women. Additionally, hegemonic masculinity emphasizes the "superiority of 'manly' men over the 'not-so-manly' men" (p. 26). This social dominance can be represented through religious practices and mass media. On the whole, the film Gully Boy makes no evident connection between the gender roles in society and nationalism. PM Narendra Modi focuses on the empowerment of women for the sake of the prosperity of the country.

When it come Othering, Pakistanis, Bangladeshis, and Indian Muslims are depicted as Others in the three analyzed films. In Raazi and PM Narendra Modi, Indians are viewed as Others by Pakistanis and vice versa. The film PM Narendra Modi compares the global performances of India and Pakistan on various occasions and continues to remind the viewers that, when it comes to accomplishment on the battlefield and sportsground, India is far better than its neighbor, Pakistan. The film PM Narendra Modi is using cricket to depict Pakistan as the Other, and it is promoting nationalism among the Indians by using pride for the country as an instrument.

Similarly, in Raazi, the protagonist is viewed as Other by a Pakistani character due to her association with India. This segregation based on national identity leads to the creation of Othering, and it is in turn being used as a tool to promote nationalism by the film, as the notion of Other is a vital component of the nationalist doctrine. As Ednor (2002) states, popular culture is often used to blend cultural and traditional rituals with other cultural elements that signifies the nation in numerous contested ways. These contested ways often lead towards the creation of Others. 
Not only the people belonging from the two neighboring countries, India and Pakistan, are portrayed as Others by characters in the films. The film Gully Boy sheds light on how the Muslim community of India can be viewed as Other by the rest of the nation.

When viewed through the lens of social identity theory (Tajfel, 1970, 1982), Muslims in the film are viewed as the members of outgroups by the Hindus who see themselves as the member of ingroup. The film mentions the social and political situation in the country, and subtly criticizes discrimination based on religion. Regardless, this portrayal of Muslims as Others can be termed as a modern version Orientalism (Said, 1978). The film presents Muslim characters with various traits ranging from conservatives to supporters of superstitious beliefs, and from violent individuals to women oppressors. This is in compliance to Ganti's (2004) belief that Hindi cinema endorses nationalist projects that mark the Muslim man as a violent other. This also indicates the existence of the notion of re-Orientalism in the film, which is the compliance with the West's construct of Orient (Lau, 2009; Lau \& Mendes, 2012; Soğuk, 1993; Zeydanlığlu, 2008). Similarly, the people belonging to the same original nation, Bangladeshis — or as the film referred to, the people of East-Pakistan — are viewed as Others by the people of West Pakistan or current Pakistan in film Raazi. The film presents this Othering as unwarranted and generally condones it through the dialogue delivery.

Another existing theme in films PM Narendra Modi and Gully Boy is class hegemony. The films depict the presence of class hegemony in India as an adverse trait that needs to be addressed. The people who challenge the system are depicted as courageous visionaries who should be leading the nation and providing hope to the people. Whereas Modi's character is depicted as a brave individual fighting class hegemony to attain power to serve the country, 
Murad's character ends up detesting nationalism due to the injustices of the society. The portrayal of class hegemony is another less-explored area in research.

Utilizing the framework of Burke's Pentad analysis provided a better understanding of the messages embedded in the films. The symbols, settings, and backgrounds of relevant scenes were studied collectively to recognize the intended message; This provided a deeper understanding of how placement of scene, actions, and actors represent the situations of society, social values, and historical events. The film Raazi presented nationalism and self-sacrifice in a glorified manner through a major part of its plot. The story of Raazi revolves around Sehmat, the main agent in the film, who is presented to perform the action of deliberately putting her life in danger to provide important information to her country's security agency. The agent's action corresponds with the setting that had already established a need for the nation to be saved, as it is being planned to be attacked by the enemy. Sehmat's action is portrayed to be performed due to embedded values, ideas, instincts, and desire, which includes her existing love for the nation, desire to the nation flourish, believe that nation comes before everything else, and her family's previous sacrifices for the country,

The film PM Narendra Modi contains overtly nationalistic messages. The film's protagonist Modi is portrayed as an agent whose actions are a result of his unconditional love and respect for his country. Although PM Narendra Modi contains multiple scenes that contain the messages of nationalism and self-sacrifice, an example of the representation of this rhetoric is when Modi decides to go on with his public address despite the threats. Here, the scene is set with the background information that the country requires Modi's leadership skills, and the idea that if he does not go further with his address, the result of the elections will be negatively affected. Modi, the agent, performs the action of going forward with his address which is 
motivated by the embedded values that are taught by his mother, his love for his country, and his desire to change the destiny of his nation.

Overall, Gully Boy questions the adequacy of nationalism. The film contains multiple agents who represent the youth of India, and they present the idea of extreme nationalism as a toxic trait through the lyrics of their rap songs. The main example of this is the song called Jingoism. In the film, the song Jingoism is performed by underprivileged youth. The setting of the song establishes that these agents have bigger concerns than politics and international relations of their country. The agents' agenda is to voice their concerns and shed a light on more important issues and existing injustices in the Indian society, and their motivation is fueled by their personal experiences, the values that they learn on their own as a direct result of their experiences, and their desire to change the society.

\section{Implications}

Disturbances in India due to agitation between members of different religious groups are not new; however, the recent years have witnessed a surge in such incidents. This study correlates to the current situation in India, where 53 people have died as a result of recent riots between Hindu and Muslim population in Delhi (Yasir \& Perrigo, 2020). The stimulating sentiments in the name of nationalism, and Othering people based on their national origins, tribes, religions, languages, and races are not only limited to South Asia. It is important to evaluate the created content being created in other regions of the world and understand its impact on power distribution and governmental policymaking.

An interesting finding of this study is the use of songs by Bollywood films to further highlight the themes that are established through dialogues. The main idea of Raazi concerns nationalism. The film contains four songs; two out of these four songs are about nationalism, and 
the third song discusses general determinism. The main themes of PM Narendra Modi are love for one's country and association with one's religion. There are six songs in the film; three out these six songs are about nationalism, two songs are about finding God and religious association, and the remaining song praises the personality of the protagonist Modi. Gully Boy contains 16 songs. The film challenges class hegemony through its plot. Eight songs of the film address class hegemony, three songs are about self-determinism, and one song is about jingoism. A study mostly focusing on the songs of Bollywood films can potentially find interesting results, since songs are central part of Bollywood films and Bollywood songs are famous among its consumers around the globe.

Studying films that challenges the notion of extreme nationalism can open new directions for not only researchers but filmmakers. Media plays a major role in allowing consumers to relate themselves to others (Anderson, 1991). Films created on subjects will well-researched impacts can play a significant role in creation of content that can possibly lead to a more harmonious relationship between members of different religious groups and nations. Specifically, in today's environment where film streaming applications are only a click away, and tolerance seems to be lacking in the society, filmmakers should research the impact of different messages their films create, and they should create films with the potential of positive contribution towards the society. Considering the reach of films and the current political and social environment, it can be concluded that well-researched films can make an impact on the audiences.

Language is a limitation of this study. The films are originally in Hindi language, with only excerpts translated into English for the purpose of analysis. When translated in a different language, dialogues often lose their original meaning, and hence it becomes difficult to study the 
use of certain words, phrases, and sentence structures and to analyze their meanings and motives. Furthermore, this study only focuses on three Bollywood films, a larger sample should be studies in order to attain better understanding of the presence of the studied themes.

\section{Conclusion}

This study explored the portrayal of nationalism and religious identity in Bollywood films. The findings of this study indicate presence of nationalism in all analyzed film. Out of the three analyzed films, one film depicts nationalism as noble, while subtly questioning the cost of sacrifice for the country. The second film views nationalism through an overtly positive lens, and the third film present blatant and extreme nationalism as a toxic trait. Religion, despite being depicted as an important factor, is presented as an aid to nationalism. Similar to religion, other existing themes, such as patriarchy, the notion of Othering, and class hegemony, spiral around the concept of nationalism. This study contributes towards the better understanding of subjects of Bollywood films, representation of nationalistic and religious identities, and, in succession, their impact on the current political situation that goes farther than merely South Asia. 


\section{REFERENCES}

Ahmad, M. (2019, March 28). Nobody wins when Bollywood and Lollywood go to war. TheOutline.com. Retrieved from https://theoutline.com/post/7251/bollywood-banpakistan-lollywood-india?zd=1\&zi=u54nhh4x.

Ahmed, S., \& Matthes, J. (2017). Media representation of Muslims and Islam from 2000 to 2015: A meta-analysis. International Communication Gazette, 79(3), 219-244.

Aithal, V.(2019, February 2019). Jingostan: Rise of the lazy nationalist. Medium.com. Retrieved from https://medium.com/@nuwandavek/jingostan-rise-of-the-lazy-nationalist-b029dca2c930

Ali, S., \& Ripley, S. D. (1983). Handbook of the birds of India and Pakistan (compact edition). Oxford University Press and BNHS, Mumbai.

Anand Math. (n.d.). IMDB.com. Retrieved from https://www.imdb.com/title/tt0215515/.

Anderson, B. (1991). Imagined communities: Reflections on the origin and spread of nationalism. New York, NY: Verso.

Appadurai, A. (1996), Modernity at Large: Cultural dimensions of globalization (Vol. 1). Minneapolis, MN: University of Minnesota Press.

Bjp. (2018, December 27). Riveting tale of how a family held the country to ransom for 10 long years. Twitter.com. Retrieved from https://twitter.com/BJP4India/status/1078319849082839041?ref_src=twsrc ${ }^{\wedge}$ tfw $\mid$ twcamp $^{\wedge}$ tweetembed|twterm^1078346280928247809\&ref_url=https://www.indiatoday.in/india/st ory/accidental-prime-minister-manmohan-singh-congress-bjp-spar-1418748-2018-12-28.

Bonnell, A., \& Hunt, L. (1999). Beyond the cultural turn. Berkeley, CA: University of California Press. 
Cavendish, M. (2007). World and its peoples: The Arabian Peninsula. New York, NY: Marshal Cavendish Corporation.

Chotiner, I. (2019, May 24). An Indian political theorist on the triumph of Narendra Modi's Hindu nationalism. NewYorker.com. Retrieved from https://www.newyorker.com/news/q-anda/an-indian-political-theorist-on-the-triumph-of-narendra-modis-hindu-nationalism.

Dasgupta, R. K. (2015). The visual representation of queer Bollywood: Mistaken identities and misreadings in Dostana. JAWS: Journal of Arts Writing by Students, 1(1), 91-101.

Desai, J. (2005). Planet Bollywood: Indian cinema in Asian America: Asian American popular culture. In S. Davé, L. Nishime, \& T. G. Oren (Eds.), East Main Street: Asian American popular culture, (pp. 55-71). New York, NY: New York University Press.

Dhillon, A. (2019, April 29). 'A narrative is being built': Bollywood's battle for Indian hearts and minds. Theguardian.com. Retrieved from: https://www.theguardian.com/film/2019/apr/29/a-narrative-is-being-built-bollywoodsbattle-for-indian-hearts-and-minds

Doniger, W. (2019, October 31). Hinduism and its complicated history with cows (and people who eat them). Theconversation.com. Retrieved from http://theconversation.com/hinduism-and-its-complicated-history-with-cows-and-peoplewho-eat-them-80586.

Dudrah, R. (2012). Bollywood travels: Culture, diaspora and border crossings in popular Hindi cinema. Abingdon, UK: Routledge.

Dudrah, R. K. (2006). Bollywood: Sociology goes to the movies. New Delhi, India: SAGE. Edensor, T. (2002). National identity, popular culture and everyday life. Oxford, UK: Bloomsburg Publishing. 
Edward, S. (1979). Orientalism. New York, NY: Random House.

Elections 2014 Results: Narendra Modi wins Vadodara Lok Sabha seat by over 5.70 lakh votes. (2014, May 16). IndiaTimes.com. Retrieved from https://economictimes.indiatimes.com/news/politics-and-nation/elections-2014-resultsnarendra-modi-wins-vadodara-lok-sabha-seat-by-over-5-70-lakhvotes/articleshow/35210970.cms.

Electoral Commission halts Narendra Modi biopic. (2019, April 12). Cnn.com. Retrieved from https://www.cnn.com/india/live-news/india-election-2019-latest-updatesintl/h_a82ad1d08e6508875b9933a3bce2586c.

Friedland, L. A. (2001). Communication, community, and democracy: Toward a theory of the Communicatively Integrated Community. Communication Research, 28(4), 358-391.

Friedland, R. (2001). Religious nationalism and the problem of collective representation. Annual Review of Sociology, 27(1), 125-152.

Ganguly, S. (1995). Wars without end: the Indo-Pakistani conflict. The Annals of the American Academy of Political and Social Science, 541(1), 167-178.

Ganti, T. (2004). Bollywood: A guidebook to popular Hindi cinema. New York, NY, and London, UK: Routledge.

Gokulsing, K. M., \& Dissanayake, W. (2012). From Aan to Lagaan and Beyond: A Guide to the study of Indian cinema. Staffordshire, UK: Trentham Books.

Grzymala-Busse, A. (2019). Religious Nationalism and Religious Influence. Oxford Research Encyclopedia of Politics. New York City, NY: Oxford University Press.

Hansen, B. S., \& Parpola, A. (Eds.). (1986). South Asian religion and society. Curzon Press. 
Hartmann, P. G., \& Husband, C. (1974). Racism and the mass media: A study of the role of the mass media in the formation of white beliefs and attitudes in Britain. London, UK: DavisPoynter.

Hoppenstand, G. (1992). Yellow devil doctors and opium dens: The Yellow Peril stereotype in mass media entertainment. In Nachbar, J., \& Lause, K. eds. Popular Culture: An introductory text, 277-291.

How worried should we be about India's population explosion? (n.d.). Indiatimes.com. Retrieved from https://timesofindia.indiatimes.com/india/how-worried-should-we-be-about-indiaspopulation-explosion/articleshow/70711314.cms.

Hult, V., \& King, K. A. (2011). Terrorism, nationalism and westernization: Code switching and identity in Bollywood (Eds.). Educational linguistics in practice: Applying the local globally and the global locally, 1, 27-40.

Hussein, N., \& Hussein, S. (2015). Interrogating practices of gender, religion and nationalism in the representation of Muslim women in Bollywood: contexts of change, sites of continuity. Exchanges: The Interdisciplinary Research Journal, 2(2), 284-304.

India 'cow vigilantes' lynch three men. (2019, July 19). Bbc.com. Retrieved from https://www.bbc.com/news/world-asia-india-49049372.

India job data spells trouble for Narendra Modi. (2019, January 31). Bbc.com. Retrieved from https://www.bbc.com/news/world-asia-india-47068223.

India-China War of 1962: How it started and what happened later. (2018, November 21). Indiatoday.com. Retrieved from https://www.indiatoday.in/education-today/gk-currentaffairs/story/india-china-war-of-1962-839077-2016-11-21. 
Indian war and patriotic movies. (2017, June 24). Imdb.com. Retrieved from https:/www.imdb.com/list/ls074940032/.

Islam, M. (2007). Imagining Indian Muslims: Looking through the Lens of Bollywood Cinema. Indian Journal of Human Development, 1(2), 403-422.

Is Bollywood complicit in pushing Modi's right-wing agenda. (2020, February 14).

Aljazeera.com. Retrieved from https://www.aljazeera.com/programmes/upfront/2020/02/bollywood-complicit-pushingmodi-wing-agenda-200214063438607.html

Jamkhandikar, S. (2019, April 10). Bollywood plays starring role in Modi's re-election bid. Reuters.com. Retrieved from https://www.reuters.com/article/india-election-modibollywood/bollywood-plays-starring-role-in-modis-re-election-bid-idUSKCN1RM0K5.

Kareithi, P. J. (2014). Hegemonic masculinity in media. Media and gender: a scholarly agenda for the Global Alliance on Media and Gender, 30. Paris, France: UNESCO.

Kaur, R. (2002). Viewing the eest through Bollywood: A celluloid Occident in the making. Contemporary South Asia, 11(2), 199-209.

Kaur, R., \& Sinha, A. J. (Eds.). (2005). Bollyworld: Popular Indian cinema through a transnational lens. New Delhi, India: SAGE Publications India.

Khan, S. (2009). Nationalism and Hindi cinema: Narrative strategies in Fanaa. Studies in South Asian Film \& Media, 1(1), 85-99.

Khatun, N. (2016). Imagining Muslims as the 'Other' in Muslim political films. Journal of Arab \& Muslim Media Research, 9(1), 41-60.

Khatun, N. (2018). Love-Jihad' and Bollywood: Constructing Muslims as 'Other. Journal of Religion \& Film, 22(3), 8. 
Kinnvall, C. (2004). Globalization and religious nationalism: Self, identity, and the search for ontological security. Political Psychology, 25(5), 741-767.

Kumar H. M., S. (2013). Constructing the nation's enemy: Hindutva, popular culture and the Muslim "other" in Bollywood cinema. Third World Quarterly, 34(3), 458-469.

Lau, L. (2009). Re-Orientalism: The perpetration and development of Orientalism by Orientals. Modern Asian Studies, 43(2), 571-90.

Manmohan Singh: India's 'accidental PM' biopic causes stir. (2019, January 18). Bbc.com. Retrieved from https://www.bbc.com/news/world-asia-india-46861434.

Masci, D. (2017, January 31). World Muslim population more widespread than you might think. Pewresearch.com. Retrieved from https://www.pewresearch.org/facttank/2017/01/31/worlds-muslim-population-more-widespread-than-you-might-think/

Matusitz, J., \& Payano, P. (2011). The Bollywood in Indian and American perceptions: comparative analysis. India Quarterly, 67(1), 65-77.

Merelli, A. (2019, December 30). The state of global right-wing populism in 2019. Quartz.com. Retrieved from https://qz.com/1774201/the-global-state-of-right-wing-populism-in-2019/

Modi biopic should not be released till the end of general elections, says Election Commission. (2019, April 10). Thehindubusinessline.com. Retrieved from https://www.thehindubusinessline.com/news/national/ec-bans-modi-biopic-duringelection-period/article26791776.ece.

Mohammad, R. (2007). Phir bhi dil hai Hindustani (Yet the heart remains Indian): Bollywood, the 'homeland' nation-state, and the diaspora. Environment and Planning Society and Space, 25(6), 1015-1040. 
Mudambi, A. (2013). Another look at orientalism:(An) othering in Slumdog Millionaire. Howard Journal of Communications, 24(3), 275-292.

Nayak, M. (2006). Orientalism and 'saving' US state identity after 9/11. International Feminist Journal of Politics, 8(1), 42-61.

Nielsen, K. (1998). Liberal nationalism, Liberal democracies and secession. University of Toronto Law Journal, 48(2): 253-295.

No PM Narendra Modi biopic release before May 19: Election Commission tells Supreme Court. (2019, April 24). Indiatoday.com. Retrieved from https://www.indiatoday.in/movies/bollywood/story/no-pm-narendra-modi-biopic-releasebefore-may-19-election-commission-tells-supreme-court-1508847-2019-04-24.

Ogden, C. (2012). A lasting legacy: The BJP-led national democratic alliance and India's. Politics Journal of Contemporary Asia, 42(1), 22-33.

Osuri, G., \& Banerjee, B. (2004). White diasporas: Media representations of September 11 and the unbearable whiteness of being in Australia. Social Semiotics, 14(2), 151-171.

Pavan Kumar, M. (2012). Introduction: Orientalism (s) after 9/11. Journal of Postcolonial Writing, 48(3), 233-240.

Pramucitra, S. (2018). Honesty value on film pentad analysis on short movie Djitoeng. Advances in Social Science, Education and Humanities Research, 206.

Rajadhyaksha, A. (2003). The 'Bollywoodization' of the Indian cinema: cultural nationalism in a global arena. Inter-Asia Cultural Studies, 4(1), 25-39.

Rasul, A., \& Proffitt, J. M. (2011). Bollywood and the Indian Premier League (IPL): the political economy of Bollywood's new blockbuster. Asian Journal of Communication, 21(4), 373 388. 
Reicher, S., \& Hopkins, N. (2001). Self and nation. London, UK: Sage.

Roy, A. G. (Ed.). (2012). The magic of Bollywood: At home and abroad. SAGE Publications India.

Sarbjit. (n.d.). Legendglobalstudio.com. Retrieved from: http://legendglobalstudio.com/sarabjit.php

Said, E. (1984). Orientalism reconsidered: Postcolonial criticism. Abingdon: UK: Routledge. Schein, L. (1997). Gender and internal orientalism in China. Modern China, 23(1), 69-98.

Shaheen Jack. 2009. Reel Bad Arabs: How Hollywood Vilifies a People. Northampton, MA: Olive Branch Press.

Soanes, C. (2006). Compact Oxford English Dictionary for University and College Students, 548. Oxford: Oxford University Press.

South Asia: Gujarat riot death toll revealed. (2005, May 11). Bbc.com. Retrieved from http://news.bbc.co.uk/2/hi/south_asia/4536199.stm.

Srivastava, N. (2009). Bollywood as National(ist) Cinema: Violence, Patriotism and the National-Popular in Rang De Basanti. Third Text, 23(6), 703-716.

Stets, J. E., \& Burke, P. J. (2000). Identity theory and social identity theory. Social Psychology Quarterly, 63, 224-237.

Tajfel, H. (1970). Experiments in intergroup discrimination. Scientific American, 223(5), 96-103. Tajfel, H. (1982). Social psychology of intergroup relations. Annual Review of Psychology, 33(1), 1-39.

Takhar, A., Maclaran, P., \& Stevens, L. (2012). Bollywood cinema's global reach: consuming the "Diasporic Consciousness". Journal of Macromarketing, 32(3), 266-279. 
Thakur, C. (2019, May 28). How PM Narendra Modi biopic helped Vivek Oberoi bag his first hit since his Bollywood debut. Indiatoday.com. Retrieved from https://www.indiatoday.in/movies/bollywood/story/how-pm-narendra-modi-biopichelped-vivek oberoi-bag-his-first-hit-since-his-bollywood-debut-1536875-2019-05-28.

The triumph of Modi propaganda in Bollywood. (2019, February 5). Scmp.com. Retrieved from https://www.scmp.com/week-asia/society/article/2184614/triumph-modi-propagandabollywood.

Totti, X. (1987). The making of a Latino ethnic identity. Dissent, 34(4), 537-542.

Triandafyllidou, A. (1998). National identity and the 'other'. Ethnic and Racial Studies, 21(4), 593-612.

Tyrrell, H. (2004). Bollywood versus Hollywood. The globalization reader, 312-318.

Uri: The Surgical Strike. (n.d.). Imdb.com. Retrieved from https://www.imdb.com/title/tt8291224/plotsummary.

Van der Veer, P. (2000). Religious nationalism in India and global fundamentalism. Globalization of Social Movements, 315-339.

Van Dijk, T. A. (1999). Discourse and racism. Discourse and Society, 10, 148- 159. Xypolia, I. (2017). British Imperialism and Turkish Nationalism in Cyprus, 1923-1939: Divide, Define and Rule. Routledge.

West, R., \& Turner, L. H. (2018). Introducing communication theory: Analysis and application ( $4^{\text {th }}$ ed.). New York City, NY: McGraw-Hill Education.

Yasir, S., \& Perrigo, B. (2020, March 3). Delhi riots: What's next for India's Muslims? Retrieved from https://time.com/5794354/delhi-riots-muslims-india/ 
Zeydanlıoğlu, W. (2008). The white Turkish man's burden: Orientalism, Kemalism and the Kurds in Turkey. Neo-colonial Mentalities in Contemporary Europe, 4(2), 155-174. 